NBER WORKING PAPER SERIES

\title{
ROUNDING THE CORNERS OF THE POLICY TRILEMMA: SOURCES OF MONETARY POLICY AUTONOMY
}

\author{
Michael W. Klein \\ Jay C. Shambaugh \\ Working Paper 19461 \\ http://www.nber.org/papers/w19461
NATIONAL BUREAU OF ECONOMIC RESEARCH
1050 Massachusetts Avenue
Cambridge, MA 02138
September 2013

We thank Maury Obstfeld, Linda Goldberg, Olivier Jeanne, and participants at seminars at American University, Johns Hopkins University, London Business School, Queens College (Belfast), Trinity University (Dublin), and ETH (Zurich) for comments. We also thank the organizers, participants, and in particular our discussants Keen Meng Choy and Menzie Chinn at the Bank of Japan's International Monetary and Economic Studies conference and the NBER Summer Institute International Finance and Macroeconomics meetings. We thank Anthony Trifero and Patrick O'Halloran for research assistance and Hiro Ito, Menzie Chinn, and Bilge Erten for sharing data. Shambaugh thanks the Institute for International Economic Policy for research support. Shambaugh thanks the Institute for International Economic Policy for research support. Shambaugh worked as a visiting scholar at the IMF while working on this paper, but the paper in no way reflects the views of the IMF, nor of the National Bureau of Economic Research.

NBER working papers are circulated for discussion and comment purposes. They have not been peerreviewed or been subject to the review by the NBER Board of Directors that accompanies official NBER publications.

(C) 2013 by Michael W. Klein and Jay C. Shambaugh. All rights reserved. Short sections of text, not to exceed two paragraphs, may be quoted without explicit permission provided that full credit, including (C) notice, is given to the source. 
Rounding the Corners of the Policy Trilemma: Sources of Monetary Policy Autonomy

Michael W. Klein and Jay C. Shambaugh

NBER Working Paper No. 19461

September 2013

JEL No. E52,F3,F33,F41

\begin{abstract}
$\underline{\text { ABSTRACT }}$
A central result in international macroeconomics is that a government cannot simultaneously opt for open financial markets, fixed exchange rates, and monetary autonomy; rather, it is constrained to choosing no more than two of these three. In the wake of the Great Recession, however, there has been an effort to address macroeconomic challenges through intermediate measures, such as narrowly targeted capital controls or limited exchange rate flexibility. This paper addresses the question of whether these intermediate policies, which round the corners of the triangle representing the policy trilemma, afford a full measure of monetary policy autonomy. Our results confirm that extensive capital controls or floating exchange rates enable a country to have monetary autonomy, as suggested by the trilemma. Partial capital controls, however, do not generally enable a country to have greater monetary control than is the case with open capital accounts unless they are quite extensive. In contrast, a moderate amount of exchange rate flexibility does allow for some degree of monetary autonomy, especially in emerging and developing economies.
\end{abstract}

\author{
Michael W. Klein \\ Fletcher School \\ Tufts University \\ Medford, MA 02155 \\ and NBER \\ michael.klein@tufts.edu \\ Jay C. Shambaugh \\ George Washington University \\ Elliot School for International Affairs \\ 1957 E Street, N.W. Suite 502 \\ Washington, D.C. 20052 \\ and NBER \\ jshambaugh@gwu.edu
}




\section{Introduction:}

Policy makers cannot have it all, at least in the sphere of international macroeconomics. This is the idea behind the policy trilemma, a central principle of international macroeconomics that asserts that a country can maintain only two of three policies; a fixed exchange rate, open capital markets, and domestic monetary autonomy. The reason is fairly straightforward. If a country has a credible fixed exchange rate and open financial markets, its interest rate must follow that of the base country, which implies sacrificing monetary autonomy. Otherwise, for example, an increase in the base country interest rate that is not matched by the domestic country would lead to investors shifting funds to assets denominated in the higher interest rate currency, which generates a depreciation of the exchange rate. Thus, monetary autonomy requires that a country must either allow the exchange rate to change or shut down the flow of finance across borders.

The policy trilemma is often depicted using the diagram presented in Figure 1. Each of the corners of the triangle represents one of the three policy choices. A government can choose a position represented by one of the sides of the triangle: a floating exchange rate with monetary autonomy and capital mobility (side A); a pegged exchange rate with capital mobility but no monetary autonomy (side B); or monetary autonomy and a pegged exchange rate, but with capital controls (point C). A strict interpretation of the trilemma means that countries are forced to one of these sides. A more tempered view is that the trilemma highlights real-world tradeoffs; if financial markets are open, more autonomy requires more exchange rate flexibility or, conversely, if the exchange rate is to remain stable, more autonomy would require a more closed capital market.

In this paper, we consider these tradeoffs, with a focus on the extent to which monetary policy autonomy can be achieved with temporary or partial capital controls rather than pervasive barriers, or with an exchange rate policy that allows limited currency fluctuations as opposed to a free float. We consider facets of middle-ground policies for both capital controls and exchange rate pegs, and the possible choices that arise along both the dimensions of time and policy intensity. Middle-ground policies arise in the time dimension through blended behavior across years, such as opening and closing the financial account, or flipping back and forth across exchange rate regimes. Policy middle grounds in a particular year are represented by loose pegs and limited capital controls.

Recent experience shows the importance of considering middle-ground policies for exchange rate regimes. While there are some cases of movement towards "bipoloar" exchange rate regimes, as suggested by Fischer (2001) more than a decade ago, and as exemplified by the move from the EMS 
bands to a single currency in the euro-zone, there remains an important and empirically relevant middle ground between long-standing pure pegs and floats. One aspect of this is the continued presence of "soft" pegs whereby exchange rates fluctuate within a wider band than with harder pegs. Another is the flipping back and forth between pegs and floats (Klein and Shambaugh (2008)).

Middle ground policies with respect to capital controls have been the subject of increasing theoretical interest and policy debate since the onset of the financial and economic crisis. Many in the international policy making community had been skeptical about using capital controls to generate autonomy. In the wake of the crisis, however, there has been a re-evaluation of the desirability of capital controls, especially those restrictions that are imposed episodically at times of incipient inflow surges. Perhaps most notably, in a reversal from their earlier stance, the IMF has suggested capital controls may be warranted under certain conditions (see Ostry et al, 2012). Theoretical work supports these views, with models showing that targeted capital controls, used in a flexible manner, could serve a prudential role and reduce financial fragility (Jeane (2011, 2012), Jeanne and Korinek (2010), Korinek (2011), Bianchi (2011)) or, for countries with pegged exchange rates, could substitute for monetary policy autonomy and provide those countries with some control over macroeconomic policy management (Farhi and Werning (2012) and Schmitt-Grohe and Uribe (2012)). Empirically, we observe some countries having long-standing, pervasive capital controls, but also a substantial subset of countries use limited controls on an episodic basis. Klein (2012) calls these capital control regimes "walls" and "gates," respectively, and shows that walls are more effective than gates in limiting asset price booms and swings in the value of the real exchange rate. In addition, in any given year, there is a wide range of scope with which capital controls are employed, generating an extensive middle ground between open and closed.

This paper investigates the consequences for monetary autonomy of middle-ground policies, with respect to both the exchange rate regime and capital controls. The analysis builds on the extensive empirical literature on test the standard policy trilemma, which focuses on tightly fixed exchange rates and strongly closed capital markets. Early results in that literature (Shambaugh (2004), Obstfeld et al (2005)) established the empirical validity of the policy trilemma . These results countered the notion that countries broadly lacked monetary autonomy, or that there was little difference in monetary autonomy that could be obtained under different exchange rate regimes. Subsequent work supports the relevance of the trilemma. Bluedorn and Bowdler (2010) demonstrate that it holds for identified monetary policy shocks in the base country, not just for actual interest rate movements. Miniane and 
Rogers (2007) confirm that interest rates in countries that peg follow the interest rate of their base country more closely than do the interest rates of countries that float, but they do not find significant differences across their capital control regime categories. Aizenmann et al (2010) show that, in this context, movements in one policy require corresponding changes in another policy; for example, more restricted capital flows enable a country to have either more monetary autonomy or greater control over its exchange rate

In this paper, we also find results that are supportive of the basic results of the trilemma for the corner policies of strongly fixed exchange rates or substantial capital controls. We add to those findings by documenting that countries that do not follow the base rate as closely (e.g. floating countries) tend to respond to their own economy more closely - suggesting that they are able to use the monetary autonomy that floating provides to pursue domestic goals.

Regarding temporary or partial regimes, we find that gates do not provide the same monetary autonomy as walls, and that the sharp trilemma corner representing capital account openness cannot be rounded by using temporary capital controls unless they are quite extensive. Also, moderate capital controls do not seem to provide autonomy, only countries whose markets are tightly controlled seem to be insulated from the base country's interest rate. Similarly, flipping exchange rate regimes does not change the general nature of the trilemma. A country's interest rate moves with the interest rate of its base country when it pegs its exchange rate, and its interest rate does not behave in this way when it does not peg. Thus a temporary float offers monetary autonomy, and monetary autonomy is foregone with a pegged exchange rate, even if it is a temporary peg. However, soft pegs do seem to generate more monetary policy autonomy than hard pegs, but not as much autonomy as floating exchange rates.

Overall, the results presented in this paper confirm the basic message of the trilemma; pegs and open countries have less monetary autonomy, and efforts to gain autonomy through middle range policies may be difficult. The most simple and most sure way to get monetary autonomy, without strongly closing off the capital account, is to allow more flexibility in the exchange rate.

\section{Methodology}

The trilemma does not require that countries only occupy corner solutions, rather it is an expression of the trade-offs faced by policy-makers, especially as regards the extent of monetary autonomy. The key question in this paper is the extent to which the trilemma trade-offs with respect to monetary autonomy are materially altered by allowing some degree of exchange rate flexibility short of 
a complete float, or by using capital controls episodically rather than erecting longstanding walls against capital flows.

We answer this question with modified versions of the approaches used in Shambaugh (2004) and Obstfeld et al. (2005). The core methodology begins from the simple interest parity equation

(1) $R_{i t}=R_{b i t}+\% \Delta E_{i t}^{e}+\rho_{i t}$

where $R_{i t}$ represents the nominal interest rate of country $i$ at time $t, R_{b i t}$ is the interest rate of the base country of country $i$ at time $t, \% \Delta E_{i t}^{e}$ is the expected change in the bilateral exchange rate between the base country and country $i$ from time $t$ to time $t+1$, and $\rho_{i t}$ represents the risk premium on the asset in question.

Under a purely credible peg with a very tightly fixed exchange rate, the expected change in the exchange rate is zero. If comparable assets issued in the domestic country and base country currencies exhibit similar risk (which might be the case with assets with relatively low risk premia, such as short term money market instruments, or short term government bonds), then the local interest rate must equal the base-country interest rate in this instance. But the local interest rate could differ from the basecountry interest rate if the exchange rate is not pegged.

Equation (1) would only hold if money can flow across borders. Impermeable capital controls break the link between $R_{i t}$ and $R_{b i t}$, regardless of the expected change in the exchange rate. Alternatively, less tight capital controls, such as a tax on foreign borrowing, could generate a wedge between $R_{i t}$ and $R_{b i t}$. With this type of tax, in the presence of net inflows (so the marginal capital came from abroad), we could rewrite (1) as:

(2) $R_{i t}=R_{b i t}+\% \Delta E_{i t}^{e}+\rho_{i t}+\tau_{i t}$

where $\tau_{i t}$ represents the tax domestic residents pay on borrowing from abroad (that is, a tax on capital inflows), which may vary over time. Raising or lowering $\tau_{i t}$ allows the government to have $R_{i t}$ move differently from $R_{b i t}$ even if $\% \Delta E_{i t}^{e}$ is equal to zero, which effectively provides monetary autonomy (Farhi and Werning (2012), Schmitt Grohe and Uribe (2012)) ${ }^{1}$.

Several challenges arise if we base our analysis on equation (2). The interest rates of countries that peg to a base country may move differently than those of the base country because of movements in

\footnotetext{
${ }^{1}$ Schmitt-Grohe and Uribe state: "As a result, the government can indirectly affect employment in the nontraded sector by manipulating the intertermporal price of tradables (the interest rate) via capital controls." It should be noted, Schmitt-Grohe and Uribe do not suggest this is a first best policy. They suggest allowing the exchange rate to change is preferable, but study the question of what should be done if that tool is not available. Farhi and Werning, argue: "In response to transitory shocks, however, capital controls now play a more important countercyclical role" when prices are sticky, and: "This discussion underscores the fact that capital controls allow the country to regain some monetary autonomy and, with it, some control over the intertemporal allocation of spending."
} 
the expected change in the exchange rate or the risk premium, both of which are unobservable. Furthermore, an extensive literature shows that equation (2) does not hold for countries that do not peg when the realized ex post exchange rate change is used as a proxy for the ex ante expected change and the risk premium is assumed to be uncorrelated with other variables. Finally, another complication arises because nominal interest rates exhibit substantial persistence and may be treated as close to a unit root. $^{2}$

For these reasons, we employ specifications that center on the first difference of equation (2), (3) $\Delta R_{i t}=\alpha+\beta \Delta R_{b i t}+\mu_{i t}$ where $\mu_{i t}=\Delta\left(\% \Delta E_{i t}^{e}+\rho_{i t}+\tau_{i t}+v_{i t}\right)$, and $v_{i t}$ is any unobserved component other than those specified. One of our empirical strategies involves estimating separate regressions for subsamples of the data, corresponding to different combinations of exchange rate regime and capital controls. For example, if we divided the sample along the dimensions of floats vs. pegs and open capital markets vs. closed capital markets, we would have four categories; floats with open capital markets, pegs with open capital markets, floats with closed capital markets and pegs with closed capital markets. We then compare estimates of $\beta$, and R-squared statistics, across these categories

In the simplest interpretation of this equation, under the assumption that $\Delta\left(\% \Delta E_{i t}^{e}+\rho_{i t}+\tau_{i t}+v_{i t}\right)$ is uncorrelated with $\Delta R_{b i t}$ (which would be true, for example if the peg was fully credible, the risk premium was constant, and there was no time-variation in capital controls), $\beta$ would equal 1 for a panel consisting of observations of open pegs because a country with a fixed exchange rate and open capital markets would need to move its interest rate one-for-one with that of the base country. More generally, in separate panels of data, the estimate of $\beta$ in a panel consisting of observations of countries with pegged exchange rates and open capital markets should be larger and more significant than the estimate of $\beta$ in a panel consisting of countries with floating exchange rates and open capital markets, or in a panel consisting of countries with fixed exchange rates and closed capital markets. Thus, $\beta$ serves as an estimated measure for monetary autonomy.

We can consider the implications for the estimate of $\beta$ in equation (3), $\hat{\beta}$, of a correlation between the base country interest rate and the regression error, $\mu_{i t}$ (which equals $\Delta\left(\% \Delta E_{i t}^{e}+\rho_{i t}+\tau_{i t}+\right.$ $\left.\left.v_{i t}\right)\right)$. Note that the formula for $\hat{\beta}$ can be written as

\footnotetext{
${ }^{2}$ Shambaugh (2004) discusses the time series properties of the data in detail. One can estimate levels relationships and test the long run relationship and speed of adjustment and use critical values that vary depending on the unit root properties of the data (see Shambaugh (2004) and Frankel et al (2005)), but doing so requires fairly long samples with the same properties. As we want to focus on shifts across exchange rate and capital controls regimes, it is difficult to find long enough episodes to use these techniques.
} 
(4) $\widehat{\beta}=\beta+\frac{\operatorname{Cov}\left(\Delta R_{b i t}, \mu_{i t}\right)}{\operatorname{Var}\left(\Delta R_{b i t}\right)}$

Based on the theory, and under the assumption that $\operatorname{cov}\left(\Delta \mathrm{R}_{b i t}, \mu_{i t}\right)$ equals zero, the estimate of $\beta$ should equal 1 for open pegs and 0 for other observations. But correlation between $R_{b i t}$ and any of the elements of $\mu_{i t}$, which includes the change in the expected rate of depreciation, the risk premium, the tax on capital flows, and other unobserved variables, affects the value of the estimated coefficient $\hat{\beta}$.

This point has implications for the manner in which we approach our empirical results. One of the unobserved variables could be a common shock that cause similar responses of interest rates across countries, even in the absence of any exchange rate management. This positive correlation between $R_{b i t}$ and $\Delta v_{i t}$, would increase the value of $\hat{\beta}$ but not represent any true loss of autonomy. If all countries experienced the same degree of common shocks, this would not bias any result regarding the difference between pegs and floats, but if pegs are disproportionately affected, we could be biased towards finding a difference. $^{3}$

Alternatively, a positive correlation between $R_{b i t}$ and the change in the expected rate of depreciation, $\Delta\left(\% \Delta E_{i t}^{e}\right)$, would increase $\hat{\beta}$ relative to its value in the absence of that correlation. This might be a relevant point if an increase in the base country interest rate raises the likelihood that a peg is broken. ${ }^{4}$ More importantly for our analysis, if the exchange rate operates within a credible target zone, then the expected depreciation decreases with an increase in the foreign interest rate because that increase moves the exchange rate closer to the reflecting upper barrier of the band and the expected rate of depreciation decreases as the exchange rate draws closer to that barrier. In this case, the correlation between $R_{b i t}$ and $\Delta\left(\% \Delta E_{i t}^{e}\right)$ is negative, which lowers the value of $\hat{\beta}$. Along these lines, Obstfeld $e t a l$. (2005) demonstrate, using simulations, that if a country is allowed some small amount of exchange rate flexibility within a band and engages in some leaning against the wind in monetary policy, a $\hat{\beta}$ of 0.5 should be expected rather than the value of 1.0 that is implied in the simplest framework. In another vein, if a decrease in the base country interest rate induces the domestic country to impose or raise the

\footnotetext{
${ }^{3}$ Results in section V which use local conditions as a control help to address this issue. Also, Shambaugh (2004) provides a number of tests looking at trade shares and other reasons a country may follow the base and finds that the core results regarding exchange rate regime and capital control regime still hold.

${ }^{4}$ If the correlation is negative for pegged countries (for example if the base country cuts interest rates in an economic crisis, but that same crisis raises doubts the local country will maintain its peg), $\hat{\beta}$ would be pushed towards zero. This would bias the results away from finding any difference between pegs and floats. .
} 
tax on capital inflows (which represents an increase in $\tau_{i t}$ ) there is a negative correlation between $R_{b i t}$ and $\mu_{i t}$, which reduces the value of $\hat{\beta} .^{5}$

These examples show that 0 and 1 do not serve as true benchmarks for the estimated coefficient in equation (3) across exchange rate regimes (due to the possible correlation between $R_{b i t}$ and $\Delta\left(\% \Delta E_{i t}^{e}\right)$ ) or across capital control regimes (due to the possible correlation between $R_{b i t}$ and $\Delta\left(\tau_{i t}\right)$ ). Some level of exchange rate flexibility or limited capital controls may mean the true $\beta$ lies somewhere between 0 and 1 and a $\hat{\beta}$ in that range may be an accurate reflection of partial but limited monetary autonomy. Thus, we do not necessarily expect $\hat{\beta}$ to equal 0 or 1 , and we try to take these factors into account by comparing $\hat{\beta}$ across subsamples or, as described below, to test for differences in $\hat{\beta}$ in a pooled sample, in order to gauge differences in monetary autonomy across exchange rate and capital control regimes.

An alternative way to consider the extent of monetary policy autonomy across exchange rate and capital control regimes, using the framework of equation (3), is to compare the R-squared statistic for a panel consisting of fixed exchange rates and open capital markets to the R-squared statistic in panels with floating exchange rates or limited capital mobility. A high R-squared shows that little else drives the local interest rate other than the base interest rate. A low R-squared shows that many other factors may drive the local interest rate. Again, Obstfeld et al. (2005) provide a benchmark for the R-squared statistic in the case of a country with a narrow target zone (which, in our empirical analysis, would be coded as a peg), which follows a monetary policy of "leaning against the wind." In this case, simulations suggest an R-squared of only 0.1 or 0.2 .

The tests on separate samples described above do not allow for an explicit test of differences in the estimates of $\hat{\beta}$ across exchange rate and capital control regimes. We can test for the statistical significance across these samples by pooling the data and using a regression that interacts the change in the base interest rate with the exchange rate regime and an indicator of capital account controls. For example, in the case of peg vs. non-peg, the equation would be

$$
\text { (5) } \Delta R_{i t}=\alpha+\beta_{R} \Delta R_{b i t}+\beta_{R P} P_{i t} \Delta R_{b i t}+\mu_{i t}
$$

where the dummy variable $P_{i t}$ equals 1 for an observation representing a pegged exchange rate for country $i$ in year $t$, and is otherwise 0 . In this equation, the effect of a change in the base country interest rate on the local interest rate is $\beta_{R}$ for a country that does not peg its exchange rate in year $t$, and $\beta_{R}+\beta_{R P}$ for a country that does peg its exchange rate in year $t$. The positive value of the coefficient $\beta_{R P}$ reflects

\footnotetext{
${ }^{5}$ As discussed in the next section, capital control data shows the presence of controls, but not their intensity nor the extent to which they are enforced, so it is not possible to include, in the regressions, a specific measure of $\tau_{i t}$.
} 
the fact that the domestic interest rate follows the base interest rate more closely when the country pegs, and a test of the significance of this coefficient offers a straightforward test for the difference between pegged and non-pegged observations. This equation can be augmented with other interactions, in particular, measures of a country's capital control regime. This specification can easily be extended to include three categories of capital controls (e.g. walls, gates and open) and/or three categories of exchange rate regimes (peg, soft peg, and float).

One disadvantage of the interaction technique is that if $\beta_{R}$ is well estimated in one sub-sample (e.g. pegs) but is noisily estimated in the other (floats), $\beta_{R P}$ may be estimated with large errors when data is pooled. This could arise if some countries with floating exchange rates, or with capital controls, change their interest rates sharply, and sometimes parallel to the movement of interest rates in their respective base country.

Time fixed effects could also be included in the regression specifications (3) or (5). These fixed effects remove any global shock to interest rates, but this strategy can only be used when there are multiple base countries; otherwise, with only one base country, the fixed effects are collinear with the base interest rate. But, even with multiple base countries, time fixed effects soak up a fair bit of information, especially to the extent that there is a correlation across base countries' interest rates. Therefore, with a limited number of bases, the use of time fixed effects may be problematic.

Throughout this paper we report estimates without these fixed effects, although we occasionally note the results obtained when using time fixed effect results (and some tables in the appendix include these results). The inclusion of country fixed effects is generally not relevant because fixed effects that differ from zero imply that a country is constantly raising (if positive) or lowering (if negative) its interest rate. Thus, including them is not justified and as a practical matter rarely has any effect on the results.

\section{Data}

A crucial aspect of any test of the trilemma is identifying the indicators of monetary policy, exchange rate regime and capital controls that can be used to test how closely the interest rate of a country follows the interest rate of the base country. In this section we discuss the indicators we use, and present some statistics.

We do not use the simple declaration by countries as to whether they are pegged or not since, as is well documented, countries often do not accurately declare their exchange rate regime. Rather, the 
core measure of a fixed exchange rate is derived from Shambaugh (2004) and is extended here to a longer sample. This approach, which focuses solely on exchange rate behavior, is better suited to an analysis of the policy trilemma than other methods of exchange rate regime classification. ${ }^{6}$

We focus on bilateral pegs. The base country is selected by the declared intent of the country, its history, or by testing against a variety of potential base countries. A country is coded as pegged in a particular year if its bilateral exchange rate with its base country stays within $a+/-2 \%$ band over the course of that year. This choice of the band width is based on the fact that through history, ranging from the arbitrage bands of the gold standard to Bretton Woods, to the EMS, bands of roughly $2 \%$ have often been allowed in fixed exchange rate systems. Countries are also considered pegged if their exchange rate is constant in 11 of 12 months but has a discrete devaluation or revaluation in the other month of that year. To avoid misclassifying a country that simply has low volatility in a given year, single year pegs are not included as pegs. There appear to be no cases in which countries are spuriously coded as pegged due to a random lack of volatility. Klein and Shambaugh (2010) document that this classification scheme has a reasonably high correlation with both de jure and other de facto classifications.

In addition to these pegs, we also consider a category of soft pegs, as in Obstfeld et al. (2010). (Henceforth, peg refers to $\mathrm{a}+/ 2 \%$ band and soft peg refers to the $+/-5 \%$ band, and float refers to all other observations). A soft peg is defined as occurring when the bilateral exchange rate with the base country fluctuates by more than $+/-2 \%$ but by less than $+/-5 \%$ in a given year, or has no month where the exchange rate changed by more than $2 \%$ up or down (as a practical matter, almost no countries qualify for the second criterion that fail to meet the first criterion). As with the peg classification, a country may not be considered as having a soft peg in a particular year if it floats in both the previous and the subsequent year, a rule that we impose in an effort to reduce the likelihood of spuriously coding

\footnotetext{
${ }^{6}$ Regarding two other popular choices, the Reinhart Rogoff classification codes countries as pegged if the black market exchange rate is stable, but that in some sense mixes two aspects of the trilemma - financial controls and exchange rate stability. For the purposes of examining the trilemma, it seems a pure focus on the exchange rate is more appropriate. Similarly, Levy Yeyati and Sturzennegar use data on reserves volatility to see if a country is intervening to maintain its peg. But, the index subsequently must add other pegs that do not intervene but that are clearly low volatility options. Furthermore due to the greater data needs, the index is available for a smaller sample of observations. See Klein and Shambaugh (2010) for an extensive discussion of the coding of exchange rate regimes, and the different types of classifications that have been used.
} 
soft pegs. ${ }^{7}$ In our binary coding, we will refer to pegs and nonpegs where the latter includes both floats and soft pegs.

Table 1A presents statistics on the exchange rate regime for the two data sets used in the analyses in this paper, the 1973 - 2011 data and the shorter 1995 - 2011 data. (The data sets correspond to the two different capital control measures discussed below. The shorter data set also includes fewer countries than the longer data set.) In the Gates and Walls data set, there is a roughly even division across the three exchange rate regime categories of peg, soft peg, and floating. The longer data set has a relatively higher proportion of pegs, a relatively lower proportion of soft pegs, and a slightly smaller proportion of floating exchange rate observations. This difference is not one related to time period but country coverage. There is almost no difference, in the longer data set, in the peg / soft peg / float division in the full sample or in its post 1995 subsample. Thus, the middle ground appears sufficiently occupied to warrant investigation. ${ }^{8}$

Classifying capital control regimes is more difficult than classifying exchange rate regimes. One can choose either a de jure or de facto means of classifying exchange rate regimes, but capital controls can only be gauged using de jure measures since there is a general absence of data on gross capital flows and, even if these data were available, it is not clear what the level of gross flows would be in the case of free capital mobility. It would be difficult to determine the extent of de facto controls by considering whether rates of return are equalized across countries since this assumes efficient markets, knowledge of investors' expectations of the future value of the exchange rate, information on investor preferences and correlations of returns with other measures of risk. Thus, researchers tend to use de jure measures of the countries' laws and regulations concerning financial flows. A disadvantage of any coding that relies on laws or administrative rules, as opposed to their actual application, is an inability to measure intensity of rules or of their implementation; for example, both a $1 \%$ tax and a $20 \%$ tax would be coded as a control.

The most consistent source of cross-country data on capital controls is the Annual Report on Exchange Arrangements and Exchange Restrictions (AREAER) published by the IMF. Up until 1995, this yearbook presented binary codes across a limited number of fields (for example, controls on current account transactions, capital account transactions, and multiple exchange rates). The level of detail was

\footnotetext{
${ }^{7}$ A country can have a soft peg for only one year, since it could move from a peg to a soft peg to something other than a soft peg, or from a something other than a soft peg to a soft peg to a peg. Only soft pegs that are bordered on either side by a float are considered spurious.

${ }^{8}$ See also Popper et al (2012) and Williamson (2000) among other studies for a discussion of the fact that the middle ground does appear occupied. It is worth noting that even conventional pegs differ from the hard pegs (e.g. currency unions and currency boards) that Fischer suggested would be the logical endpoints. Roughly half of the pegs are not pure pegs but have some movement within the $2 \%$ bands.
} 
expanded dramatically in the 1995 yearbook which began to report separate indicators of controls on money market instruments (debt instruments with a maturity of 1 year or less), bonds (debt instruments with a maturity of greater than one year), financial investments (which includes bank borrowing and lending), collective investments, equities, and direct investment. Also, for the first time, separate indicators were included for regulations on inflows and outflows for each of these categories.

We use two sets of indicators of capital controls in this paper, both of which draw on the AREAER. The Chinn-Ito index (first presented in Chinn and Ito (2006)) takes the first principal component of the IMF AREAER yearbook coding of controls relating to current or capital account transactions, the existence of multiple exchange rates, and the requirements of surrendering export proceeds. This index covers a wide set of countries over a long time period, allowing for tests on a large sample of data. The annual Chinn-Ito data we use in this paper covers the 1973 to 2011 period. This classification allows for a country to be in different categories across time. As shown in Figure 2, these data are close to tri-modal, so we use these data to create three dummy variables, one for open capital accounts, one for closed capital accounts, and a third for an intermediate level of openness. ${ }^{9}$

The second set of capital control indicators use information from the post-1995 volumes of the AREAER in a manner that builds on Schindler (2009). ${ }^{10}$ We follow the strategy of Klein (2012) who distinguishes between countries that persistently had open capital accounts (open), countries that persistently had closed capital accounts (walls), and countries that used capital controls episodically (gates); thus, unlike the Chinn-Ito data, in this scheme a country does not change categories across time, although a gate can be open or closed, depending upon the absence or presence of controls in a particular year. ${ }^{11}$ This division of countries into the three categories is based on the information from the AREAER for five categories of financial flows (all but direct investment) for both inflows and outflows. ${ }^{12}$ As discussed in Klein (2012), there is a relatively straightforward separation of countries into these three categories since capital controls were imposed for long duration and over a majority of

\footnotetext{
${ }^{9}$ Comparing these cuts in the index to the old binary coding of the IMF yearbook (for the years where available), we found that the open countries were always open according to the yearbook, the closed countries were always closed, and those that are in the middle ground based on the Chinn-Ito index were sometimes coded as open and sometimes coded as closed.

${ }^{10}$ We thank Bilge Erten, who extended the country coverage of the Klein (2012) data set and kindly shared her data with us.

${ }^{11}$ In the three way coding based on the Chinn Ito index, 87 of the 134 countries change capital control status with 66 making moves in the direction of more openness, and 56 making moves in the direction of being more closed. Some countries moved back and forth, and some countries moved more than once (for example, in two steps from completely closed to completely open) generating a total of 159 moves in capital account status based on our three way coding.

${ }^{12}$ Direct investment controls can be associated with intellectual property rules, national security, or many other features separate from controlling the flow of finance. Because the indicators are highly correlated (especially for walls countries that effectively have controls on all indicators), we focus on the gates / walls distinction, not fine variation across the different indicators.
} 
categories for walls countries, while controls were almost entirely absent for the countries in the open category. For the walls countries, the average value of the ten categories (where 1 signifies a restriction and 0 represents no restriction) is .93 . That is, these countries are almost entirely closed in every year. Conversely, the open countries have an average value of .02, suggesting most never have record even a single restriction.

For the countries in the gates category, the average value for the $0 / 1$ indicators is .43 . We distinguish between years in which the capital account was closed in any way and those in which it was open. Open gates are those that have no restrictions (and hence an average value of zero); closed gates are those that have any restriction at all (average value of .54). Thus, while the open gates look very much like the open countries in general (in that there are no restrictions), closed gates are somewhat different from walls. In addition to not being long lasting, they are not as extensive even when closed. We sometimes divide the closed gates into limited gates, which equal 1 in years in which the average of the number of closed categories was greater than zero and equal to or less than 0.50 (that is, half or fewer of the 10 categories are closed, average value .29), and comprehensive gates, which equals 1 in years in which this average is greater than 0.50 (meaning more than half of the categories show a restriction, average value .82$).{ }^{13}$ Comprehensive gates are more similar to walls in their coverage of assets, though given their temporary nature, they still may be more permeable.

Table 1B reports the number of observations in each category for each classification scheme. As mentioned above, the Chinn-Ito (CI) classification allows for a country to be in different categories across time. This classification puts $37 \%$ of the 1973 - 2011 observations in the closed category, $31 \%$ in the mid-range of capital controls category, and 32\% in the open category. The Gates-Walls-Open (GWO) classification divides the data by country, not by country-year observation. It places the most observations in the gates category (48\%), the next most in the open category (29\%), with the remaining $23 \%$ in the closed category. Of those 610 gates country year observations, 123 represent years in which there are no controls in place and 487 have some type of controls on asset trade. These closed gates observations are roughly evenly split between limited gates and comprehensive gates (272 comprehensive and 215 limited).

Table 1C compares the Chinn-Ito (CI) and Gates/Walls/Open (GWO) indicators. This table shows that the vast majority of observations coded as open in GWO are also coded as open in CI. Most

\footnotetext{
${ }^{13}$ We consider other values of the cutoff separating limited from comprehensive gates as well. This is discussed in more detail in Section IV.
} 
of the GWO walls observations are in the closed CI category (with some in the mid-range). Effectively all the GWO open gates are coded as open by CI, and the closed gates are spread across all three categories. The limited closed gates are predominantly open and middle (though some are closed) and the comprehensive closed gates are predominantly middle and closed (though some are open).

These statistics show that there is an empirically relevant number of observations that are neither fully open nor fully closed capital accounts and, as with the exchange rate regime, the middle ground is a common enough outcome that it warrants investigation. We next turn to the question of whether these middle ground policies, for both exchange rate regimes and capital controls, allow for more monetary autonomy than a peg, or than a fully open capital account. ${ }^{14}$

\section{Results}

This section presents results for both a data set using the Chinn-Ito capital control data, which covers the period 1973 - 2011, and one using the gates, walls, and open division of countries, which covers the period $1995-2011$.

\section{IV.1 Core evidence on the Trilemma}

Table 2 presents subsample regressions using the longer (Chinn-Ito) data set running regressions with the specification presented in equation 3 . In the first binary split of the data, we isolate pegs from all other countries (grouping soft pegs and floats together) and isolate open countries from those with any controls (middle closed or closed capital markets). Each of the four panels of table 2 represents one of the archetypal options that the trilemma presents: open pegs, open nonpegs, closed pegs, and closed nonpegs. Each panel shows the $\beta$ coefficient (the coefficient on the base-country interest rate) as well as the standard error associated with that coefficient, the number of observations and the $\mathrm{R}^{2}$.

\footnotetext{
${ }^{14}$ The other data used in the analysis (interest rates, reserves, etc) are from standard sources and are described in the data appendix. The data set is an unbalanced panel based on data availability for exchange rates, interest rates, and capital control data. Regressions using the Chinn-Ito data set are limited to 3126 observations across 134 countries. The only limitation other than data availability is that the United States is not included as it has no logical base country (any correlation between the US and another country's interest rate is presumed to be the other country following the US). In addition, large swings in local interest rates are excluded since, in a handful of extreme cases, rates change by over 9 percentage points in a year and these observations would dominate the results. Leaving out changes of 50 percentage points or more represents roughly $1 \%$ of the observations, leaving out changes of 9 percentage points represents roughly $5 \%$ of the observations. In small samples, large but not extreme changes (between 9 and 50 percentage points) can also be large enough for one observation to dominate the estimates. We thus use the 9 percentage point cutoff for our baseline results. All main results are consistent if using the 50 percentage point change cutoff. Two other possible restrictions - dropping very small countries or dropping countries with clearly non market interest rates (ones that do not change for multiple years) - tend to strengthen the results, but these results are not reported.
} 
For open financial market pegs sample, the coefficient is 0.68 (and the base interest rate movements explain $28 \%$ of local country interest rate movements). ${ }^{15}$ Alternatively, the coefficient in the closed pegs sample is 0.40 and also highly statistically significantly different from zero, but in this case the R-squared is only half as big as in the open peg sample. Thus, despite the closed financial markets, these pegs still move in conjunction with the base interest rate. Interest rates in open float countries are also not completely uncorrelated with those of the base countries. The coefficient in this group is 0.23 and is significantly different from zero. ${ }^{16}$ Finally, interest rates in the closed nonpegs countries show almost no relationship with their respective base country interest rate. ${ }^{17}$ The coefficient is close to zero (0.09), though it is significantly different from zero at the 90 percent confidence level. ${ }^{18}$

We also investigated whether interest rates in countries that peg are following the interest rate of the base country, and not just moving with major country interest rates (results not presented in a table, but discussed here). We did this by using a sample of countries whose base country is not the United States. In the pegged sample of this subset, the coefficient on the base (non-U.S.) interest rate is 0.67 while the coefficient on the base (non-U.S.) interest rate in the nonpegged sample is 0.25 . But the coefficient on the United States interest rate in the both the peg and the nonpeg subsamples are nearly identical, with values of each in the neighborhood of 0.25 . Thus, pegged countries are not simply moving with world shocks along with the base, they are specifically reacting to their own base country interest rates. Non-U.S. based pegs float against the dollar and hence do not follow U.S. rate shocks.

The marginal column and row of Table 2 presents results from the interaction regression, which takes the general form of equation (5) but also includes an interaction for capital controls. These results allow us to test the significance of the difference in the coefficients of pegged and nonpegged, and also

\footnotetext{
${ }^{15}$ Standard errors are clustered at the country level so as to allow for an unstructured covariance matrix within a set of observations for a country (controlling for serial correlation in the panel as well as the possibility of different size errors across countries). One could alternatively control for correlation within a given year across countries, the standard errors are nearly identical across the two choices. Both clustering methods yield standard errors considerably larger than a simple heteroskedasticity correction or uncorrected errors.

${ }^{16}$ It is worth noting that incipient pegs do not drive the positive coefficient. Dropping countries that are floating but will peg sometime soon does not change the coefficient or the significance level.

${ }^{17}$ Crises do not explain the low coefficient for nonpegs. Eliminating countries that pegged the year before or two years before does not change the result.

${ }^{18}$ Appendix table $2 \mathrm{~A}$ replicates these results including year effects. To the extent that the base countries' interest rates are correlated, or that particular subsamples have one dominantly used base country, the results will be pushed towards zero as much of the variation in the base rate will be captured by the fixed effects. Additionally, if a country is not really following the base country, but simply moving together when the whole world moves, we would also see the $\beta$ moved towards zero. But the results in Table 2a show that there is little change in the coefficients in the open pegs and closed pegs subsamples, suggesting that the significant coefficients for the pegged samples are not generated by global shocks. In contrast, coefficients for both nonpeg samples move towards zero, suggesting that the nonzero $\beta$ may in fact be simply driven by common shocks for the nonpeg samples.
} 
of the difference in the coefficients on open and closed capital accounts. The difference in the effect of the base interest rate on pegs versus nonpegs is 0.33 while the difference in the effect of the base interest rate on open versus closed is 0.27 . Both of these differences are statistically significantly at the 99 percent confidence level. These results are in line with those of Shambaugh (2004) and Obstfeld et al. (2005), even though those papers have a sample period that is shorter by ten years.

The four panels of Figure 3 illustrate the results presented in Table 2. Each panel shows the scatter plots of one of the four subsamples, along with the regression line. The line is steepest and the scatter of observations is clearly tightest around the regression line for the open peg subsample. There appears to be virtually no relation between local and base rates in the closed nonpegged sample with a flat regression line and a wide scatter of data points. The spreads of the observations of the other two samples, closed pegs and open nonpegs, are between the other two subsamples.

We note that the coefficients in the off diagonal cells of Table 2 are statistically significant. This seems to indicate that complete monetary autonomy is not gained by only having a closed capital account, or by only having a floating exchange rate, but only with a floating exchange rate and a closed capital account. ${ }^{19}$ This result can be seen as at odds with a basic interpretation of the trilemma, which suggests that countries with an open capital account that do not peg (corresponding to the sample in the upper right cell) and those that peg and have a closed capital account (corresponding to the lower left cell) should have monetary autonomy. But another interpretation of the estimates in this $2 \times 2$ table is that we may need a more fine gradation of policies to understand the sources of monetary autonomy. We next turn to this point.

\section{IV.2 Rounding the Corners}

One possible reason that the interest rates of countries that are classified as not pegging follow the interest rate of the base country, as shown in the upper right cell of Table 2, is that floats may not purely float, as suggested by Calvo and Reinhart (2002). Likewise, a possible reason for the significant correlation of interest rates between the base countries and the countries that peg and have closed capital accounts, as shown in the lower left cell of Table 2, is that these countries do not really close their capital accounts. Our discussion of the data supports these interpretations of the estimates presented in Table 2 since the definition of nonpeg includes soft pegs as well as pure floats, and the binary coding for capital accounts is generated from a continuous index.

\footnotetext{
${ }^{19}$ These results are consistent with results in Obstfeld et al (2005) and Bluedorn and Bowdler (2010).
} 
In this section we test the implications of the policy trilemma when accounting for finer gradations of policy choices than simply peg or nonpeg, or open or closed. To do this, we separate soft pegs from the nonpeg group, allowing for an analysis of this policy choice and using a more homogeneous float category. We also split the observations representing mid-level closing of the capital account from those representing strongly closed capital accounts. These refinements of the categories enable us to consider whether the source of significant $\beta$ coefficients in the off diagonal cells in Table 2 is an artifact of using too broad a classification scheme for the exchange rate and capital account regimes.

Table 3 presents estimates that are based on three categories of exchange rate regime, peg, soft peg, and float, and three categories of capital account controls, open, mid-level, and closed. The $3 \times 3$ matrix in bold presents estimates from the subsamples. One way to consider these estimates in light of the policy trilemma is to compare coefficients across rows in order to look at differences across exchange rate regimes, or down columns in order to look at differences across capital account control regimes. The marginal columns and rows present estimates from the interaction regression, with the marginal columns at the right of the table presenting the estimates of the differences across capital control regimes and the marginal rows at the bottom of the table presenting the estimates of the differences across exchange rate regimes.

The estimates in Table 3 support the implications of the policy trilemma with respect to the three exchange rate regimes. The first row shows that the coefficient on the base country interest rate for the open peg sample (0.68) is larger than the coefficient for the open soft peg sample, which is itself larger than the coefficient for the open float sample. This pattern also holds for the mid-level open subsamples, as shown in the second row, and the closed subsample, as shown in the third row. In addition, the coefficients for the pegged subsamples are statistically different from zero at a 99\% confidence level while we cannot reject that the coefficients for the floating samples are equal to zero (statistical significance for the soft peg samples are in between these). The marginal rows at the bottom of the table show that there is a statistically significant difference between the coefficient on pegs and soft pegs, between pegs and floats, and between soft pegs and floats.

Thus, Consistent with the predictions of the trilemma, the coefficient on the base country interest rate for each of the three floating exchange rate subsamples (across the three capital control regimes) are close to zero and not statistically different from zero. This contrasts with the estimates in the non-peg column in Table 2, and suggests that the set of soft pegs observations is the source of the significant 
coefficients in that table. Moreover, the estimates in Table 3 suggest that soft pegs achieve the goal of affording some monetary autonomy, at least relative to instances of pegged exchange rates (though not as much as would be the case if the currency floated), while maintaining some exchange rate stability (though not as much as would be the case if there was a hard peg). ${ }^{20}$

Looking down the columns allows comparisons of the financial openness regimes. The open financial market subsamples (in the top row) always have higher coefficients (within each column) than the closed subsamples (the bottom row). The test across the categories (reported in the far right column) shows that open financial market samples have a coefficient 0.29 higher than closed (the gap is statistically significantly different from zero at 99\%). The gap is far less clear between open and midopen countries. While mid open pegs have a lower coefficient (0.54) than open pegs $(0.68)$, the gap is not large. For soft pegs and floats, the gap is even less clear. Combined, one cannot reject that mid open country year observations have the same $\beta$ coefficient as open ones. One can reject, though, that mid open observations are the same as closed. ${ }^{21}$ Thus, these estimates suggest that policy autonomy is only generated by the strongest types of capital controls. ${ }^{22}$

Considering the question posed in the introduction, it seems that there is some rounding of the corner of the policy trilemma that relates to exchange rate management; the policy interest rate of a country with a soft pegs is less correlated to the base country interest rate than is the case with pegs, but it is more correlated than is the case with a floating exchange rate. But there is less evidence that the mid-level capital controls afford policy autonomy, and that this corner of the policy trilemma remains sharp, with a distinction between closed capital accounts and the other two categories. Or, more

\footnotetext{
${ }^{20}$ There appears to be some difference across level of economic development, as coefficients for advanced economy soft pegs are closer to those of pegs than for the emerging and developing sample. Year effects, though, seem to lower the coefficients more for advanced soft pegs so the high coefficients may reflect common shocks. This issue is explored further in section $\mathrm{V}$.

${ }^{21}$ These gaps across softpegs and other regimes or mid-open countries and other regimes are quite similar and retain the same level of significance if year effects are included. See the results presented in Appendix Table 3A.

${ }^{22}$ These results hold with two other considerations included. Advanced economies tend to have tighter relationships with the base rate regardless of exchange rate regime - perhaps because they are more linked in the global economy. If an interaction term between a dummy for advanced economy and the change in the base rate is included in the regression, it draws a large and statistically significant coefficient, but does not alter the conclusions. Coefficients on the interactions with peg and softpeg are largely unaffected while coefficients on the openness of the capital account shrink slightly towards zero (as the openness and advanced country status are correlated). Furthermore, an additional way that countries could try to pursue autonomy is to use reserves to stabilize the exchange rate but use the interest rate to stabilize the economy (see Aizenmann (2011). If an interaction with high reserves holdings and change in the base rate is included (to proxy for the capacity to engage in foreign exchange intervention), the coefficient is insignificant and there is no change to other variables. Appendix Table 4a shows an interaction regression (along the lines of equation 5) with both advanced country status and high reserves holdings included.
} 
broadly, as long as capital markets are not strongly closed, pegs and soft pegs (somewhat) move with the base, and floats do not.

\section{IV.3 Temporal Changes in the Exchange Rate Regime}

Soft pegs are not the only source of a middle ground in exchange rate regimes. There is also the tendency of countries to shift back and forth between pegged and floating exchange rates (Klein and Shambaugh (2008)). In this section we examine whether there are differences in the extent of monetary autonomy across pegged categories when we take into account this temporal behavior.

Previous work has suggested that the impact of a peg may grow over time; for example, pegs in place for a long time matter more for trade than do pegs that are relatively new (Klein and Shambaugh (2006)). This difference may reflect the effect of the current length of a peg on the expectation that it will continue. Klein and Shambaugh (2008) show that the conditional likelihood that a peg will last one more year rises with the length of time on the peg. Does the impact of this durability translate to the extent of monetary autonomy? One may expect this to be the case if the durability of the peg affects the unobserved expected change in the exchange rate. Conversely, to the extent that the limits on monetary autonomy are effectively an arbitrage condition, and changes in the base interest rate transmit to changes in the domestic interest rate immediately, there may not be a temporal middle ground between longlived pegs and long-lived floats.

We investigate this question in Table 4. This table presents regressions of the form of equation (2) for different categories of exchange rate regime over the 1973 - 2011 period (but without distinguishing across capital control categories). Column 1 presents the estimates for the peg subsample as a whole. Columns 2 and 3 include observations for either long pegs (the pegs last for at least 5 years) or short pegs (less than 5 years). There appears to be no difference with regards to monetary autonomy across this division with regards to the coefficient on the base rate or its statistical significance. ${ }^{23}$ The $^{2}$ statistics on the much smaller short peg samples are lower, perhaps because there is more volatility in the local rate in the early years of a peg as it is establishing credibility.

It may be the case that the relevant consideration is not the eventual duration of the peg, but the time spent in an existing peg. We investigate this in Columns 4 and 5 which present results for subsamples that are based on the current length of a peg, regardless of the eventual duration of the full

\footnotetext{
${ }^{23}$ Note that there are far more long pegs observations than short peg observations. As noted by Klein and Shambaugh (2008), this is because, with annual data, longer pegs are sampled far more often than shorter pegs, not because there are more episodes of long pegs than episodes of short pegs.
} 
peg episode. The sample in Column 4 includes pegs in existence for 5 years or more while the sample in Column 5 includes pegs in existence for 4 years or less. It turns out that this distinction, like that of the eventual duration of the peg, does not generate significant differences with respect to monetary autonomy. The coefficients on the change in the base interest rate are virtually the same across these two subsamples. ${ }^{24}$ These results suggest that the "temporal" middle ground is not distinct from the general fact that a country pegs its currency, without regard for the length of time the peg has been in place or for the eventual duration of the peg. The monetary policy of a country with a pegged exchange rate significantly follows that of the base country.

Klein and Shambaugh (2008) show that nonpegs can be just as ephemeral as pegs, with nonpegged episodes often lasting just 2 or 3 years as a country flips back and forth from pegging and not pegging. Using the same categorizations for short and long nonpeg episodes, the coefficient on the base rate is between 0.1 and 0.2 (see columns 6 and 7). This suggests that temporary floating can in fact generate monetary autonomy - something of a contrast to the result that many gates are ineffective (shown below).

\section{IV.4 Gates and Walls}

The results presented to this point, which use the Chin-Ito definition of capital controls, do not support the idea that limited capital market interventions provide monetary autonomy. As mentioned above, the Chinn-Ito capital control measure reflects a range of factors besides the AREAER capital control indicator. An alternative indicator of capital account controls relies on the post-1995 data that distinguishes across controls on a range of asset categories. This open-gates-walls data set enable us to distinguish between countries that have longstanding controls on a wide category of assets (walls) and those that use controls episodically (gates). We can also distinguish, among the gate countries, between the presence of temporary extensive controls (comprehensive gates) and temporary controls on a more limited set of assets (limited gates). The sample for an analysis that uses these data includes 73 countries over the 1995 - 2011 period, with 34 countries in the gates category, 16 in the wall category, and 23 in the open category.

The first results using these data are presented in Table 5 which uses an interaction regression for the peg variable, as in equation (5), across capital control categories subsamples. The regressors include

\footnotetext{
${ }^{24}$ The value of these coefficients are also very similar to those for a subsample of pegs in place for only 2 years or less, and a subsample of peg episodes lasting two years or less.
} 
the change in the base interest rate, a peg dummy variable, and the interaction of the peg dummy and the change in the base country interest rate. The table reports the coefficient on the change in the base interest rate, $\beta_{R}$ (which represents monetary autonomy for countries that do not peg), the linear combination of this coefficient and the interaction, $\beta_{R}+\beta_{R P}$ (which represents monetary autonomy for countries that peg), and the coefficient on the interaction, $\beta_{R P}$ (which represents the difference in monetary autonomy between peggers and non-peggers).

The first column of Table 5 shows that pegging significantly limits monetary autonomy for the set of countries with open capital accounts, and that there is a significant difference between peggers and non-peggers for this subset. The coefficient on the base interest rate for observations representing pegged exchange rate is 0.71 and it is statistically significantly at better than the $99 \%$ level of confidence. In contrast, the coefficient for nonpeg observations is 0.11 , with a t-statistic of about 0.5 . The difference in the coefficients between pegs and nonpegs is significantly different from zero at better than the $99 \%$ level of confidence.

The last column of Table 5 shows that at the other polar extreme, countries with pervasive and longstanding capital controls (that is, walls), there is no statistically significant partial correlation between the base country interest rate and the domestic interest rate for peg observations or nonpeg observations. This results differs from those in Tables 2 and 3 in which there is some evidence of a correlation of domestic and base-country interest rates for countries that peg their currency, even in the case in which the capital account is most closed according to the Chinn-Ito index (though the point estimates are similar). While the smaller sample in the gates-walls data set may be one source of this difference, even though there are 290 observations in this subsample, another reason may be that the walls categorization better captures the difference between these countries and the rest of the sample than the categorization obtained by splitting the Chinn-Ito data into three categories. If this latter explanation holds, it may be that systematic capital controls that are left in place for long periods of time are truly effective at isolating countries from the base rate regardless of exchange rate regime.

The middle four columns of Table 5 present results for the gates countries. The first two of these columns presents the estimates for open gates and closed gates. The coefficients on the base country interest rate for peg observations are 0.61 and 0.70 , respectively, and in both cases the total effect is statistically significantly different from zero at a high level of significance. This suggests that closed gates generally provide almost no monetary autonomy and, in this way, are indistinguishable from open gates. But there is a distinction in the partial correlation of domestic and base country interest rates 
between cases of limited gates and comprehensive gates, as shown in the fourth and fifth columns of Table 5. There is a large and statistically significant partial correlation of interest rates for peg observations when countries have in place limited gates (that is, when half or fewer of the asset categories are closed) which implies that a limited imposition of capital controls does not afford monetary autonomy for pegged countries. Also, in this case, there is a statistically significant difference in the correlation between countries that peg and countries that do not peg. In contrast, the correlation between base country and domestic interest rates is about half as large, and not statistically significant at conventional levels, for the sample of observations that represent comprehensive controls on capital flows. Comprehensive episodic controls act more like walls than do limited controls.

Table 6 present estimates of the differences in the coefficients across gates-walls-open categories based on a pooled regression with interaction terms (an expanded version of equation (5)). The upper diagonal elements of these tables represent differences across coefficients for peg observations, and the lower diagonal represents differences across coefficients for non-peg observations. The estimates presented in Table 6 demonstrate that there is a statistically significant difference in the correlation between the changes in the domestic and base interest rates between open and wall countries for pegged exchange rate observations (there is no difference for on-pegs as none of the countries follow the base). There is also a significant difference between walls and limited gates, but not between walls and comprehensive gates. There is also, though, not a statistically significant gap between open and comprehensive gates for pegged countries. The fact that the coefficient on comprehensive gates is between that of open and walls countries suggests that if a country imposes controls across a wide set of asset classes, it may be able to generate some monetary autonomy, but the point estimates are somewhat noisy and it is difficult to say if comprehensive gates are truly distinct from open countries or limited gates. $^{25}$

Does this suggest countries can round the corners of the trilemma with an episodic application of capital controls? These estimates suggest that they can generate monetary autonomy by closing the financial account, but only if the impose a wide array of measures rather than a limited intervention. As noted above, our data uses administrative measures which means we cannot test for the intensity with which these controls are enforced. It may be that comprehensive gates can be imposed without completely shutting down international capital flows, but the results suggests that limited controls on a

\footnotetext{
${ }^{25}$ As the criteria to be a limited gate is increased (that is the threshold on the number of controls is raised), the comprehensive gates look more like walls and the gap to open grows larger.
} 
small set of assets will not be effective at regaining autonomy. Given the political economy difficulties often associated with making changes to capital control regimes, changes across a wide set of assets to adjust policy in response to economic conditions could be difficult.

\section{Autonomy to do what?}

Throughout this paper, we have argued that a failure to follow the base country interest rate (a low $\beta$ ) represents realized or potential monetary autonomy. In this section, we examine whether samples with lower $\beta$ adjust interest rates to local economic conditions. That is, does the lower $\beta$ allow countries to pursue interest rate policy that resembles typical monetary policy rules? This section supports the previous results both by including controls for local conditions in our estimates of the responsiveness of local interest rates to base interest rates, and also by confirming that countries with low $\beta$ are not simply buffeted by changes in exchange rate expectations or risk premia, but rather are able to use the monetary policy autonomy their more flexible exchange rate allows.

Equation 6 shows a basic Taylor monetary policy rule where the policy interest rate is a function of a constant, the output gap, and the gap between the current inflation rate and the preferred inflation rate.

(6) $\mathrm{R}_{\mathrm{it}}=\alpha+\gamma\left(\mathrm{Y}_{\mathrm{it}}-\mathrm{Y}_{\mathrm{it}}{ }^{*}\right)+\sigma\left(\pi_{\mathrm{it}}-\pi^{*}\right)$

Assuming no changes in the optimal inflation rate or $\mathrm{Y}^{*}$, the change in the policy rate should be:

(7) $\Delta \mathrm{R}_{\mathrm{it}}=\gamma(\Delta \mathrm{Y})+\sigma(\Delta \pi)$

Potential output is likely to be growing as well, so the reaction function likely includes $\Delta \mathrm{Y}^{*}$, but as long as $\Delta \mathrm{Y}^{*}$ is a constant, it will be absorbed in a constant in the regression. Thus, the change in the policy interest rate should be a function of the growth rate in the economy and the change in the inflation rate. The predictions, then, are fairly simple and intuitive. A country that has fast GDP growth rate or rising inflation in the previous year should have a higher interest rate this year than last year (that is, they should be increasing their policy rate), so that the change in the interest rate from last year to this year would be positive. In reality, policy is forward looking, takes into account higher frequency data, the changes in GDP and inflation are responding contemporaneously to changes in the policy rate, and changes in inflation are volatile. Thus, we do not suggest that the estimates of $\gamma$ and $\sigma$ are the actual coefficients used in a policy reaction function. ${ }^{26}$ Rather, we are interested in whether the change in the

\footnotetext{
${ }^{26}$ Clarida et al (1998) produce a test similar in spirit to examine the extent to which the U.S., Germany, and Japan follow an inflation targeting like rule and to what extent the UK, Italy, and France follow that rule or are influenced by Germany's
} 
policy rate reacts to local growth and inflation at all. Thus, we focus on the F-test for the joint significance of these variables as a signal whether the local interest rate responds to local conditions. ${ }^{27}$ The simplest form of the trilemma suggests that this would not be the case for a country with an open capital market and a pegged exchange rate.

We test whether countries use autonomy in a way consistent with this rule by including GDP growth and the change in the inflation rate along with the change in the base country interest rate for different subsamples. We focus on the advanced and emerging economy samples as they are the ones most likely to be using monetary policy that approximates a Taylor rule if unconstrained, though we split the sample across these two groups as they likely use different policy reaction functions. Also, there is a concern that the 1970s in particular, but also to some extent the 1980s may have had different policy rules prior to the "Great Moderation". We thus limit our sample to 1990-2011. We split the sample by exchange rate regime (peg, soft peg, and float) as previous results suggested these were the most relevant distinctions. In this smaller sample, there are not enough observations of closed economies for separate estimation, so we focus on pooled results for open and mid-open observations (as previous results suggested they were similar). ${ }^{28}$

If a country has no autonomy and simply follows the base, the local conditions should have zero coefficients. If the country has autonomy and can respond to its own shocks, the base interest rate should have a zero coefficient and the local conditions should explain the interest rate change. It should be noted that the familiar problem of identifying the effect of monetary policy holds here in some regard. In the classic story, if a central bank is able to move rates in a way that perfectly stabilizes the economy, it will appear that it has had no effects because the interest rate is changing but there is no response in the economy. In this case, if the central bank is able to keep inflation perfectly at its optimum and keep output at full employment, it will be changing rates to respond to shocks, but the inflation and GDP growth variables will be constants, so it will appear that the central bank is changing rates, but not in response to these variables. With more detailed data focused on a smaller set of

\footnotetext{
monetary policy. They find the EMS countries operate differently and that the constraint of Germany's interest rate has meaningful effects. They use a forward looking rule and allow for individual country policy rules.

27 The fact that local conditions may respond to the local interest rate would in fact bias the coefficients towards zero as higher interest rates should depress growth and inflation (a negative correlation rather than the positive one in the reaction function).

${ }^{28}$ The sample changes for two reasons from the earlier results. First, some countries lack inflation or real GDP growth data (in the WDI database). Second, once again, large outliers have been excluded - we trim $1 \%$ outliers on either side for both changes in inflation and GDP growth. Since the large outliers in interest rate changes are already excluded, many of the most volatile economic outcomes are already excluded from the sample.
} 
countries, Clarida et al (1998) test a forward looking rule that examines if six advanced country central banks are responding to changes in forecasts of inflation, and find countries in the European Monetary System follow Germany more than floating countries and follow their own economies less.

Table 7 reports, for each subsample, the coefficients on the base interest rate changes, GDP growth and changes in inflation as well as an F-test for the joint significance of the domestic variables. Results for the advanced economies are in the first panel. Pegged countries (first column) do not respond to either changes in inflation or GDP growth. The coefficient on the base rate, though, is nearly 1 - further evidence that the results in section IV are not driven by pegged countries that pursue their own policy goals that just happen to be correlated with the base interest rate. For soft pegged advanced countries, there is a positive and statistically significant response to changes in inflation, and the F-stat on the joint significance of inflation and growth is 3.4, implying significance at nearly $95 \%$. The coefficient on the base interest rate is .75, still quite high, but lower than for pegs and consequently, the attention paid to local variables is higher. For floats, there is a positive statistically significant coefficient on GDP growth, and the F-stat on the joint significance of inflation and growth is 4.3, implying the local variables have a significant impact on changes in the policy rate. The open floats still show a positive correlation with the base country ( $\beta$ is .44$)$, but are able to respond to their own economy as well.

The lower panel reports a similar set of tests for the emerging market sample. Open pegs respond to the base rate strongly (.69), and do not respond to their own economy (the F-stat is nearly zero). Soft pegs have effectively a zero coefficient on the base interest rate - implying substantial monetary autonomy under our assumptions - and they have a strong positive coefficient on local inflation and an F-test of 8.9 (indicating the variables are jointly significant at the $99 \%$ level). Finally, floats have a statistically significant coefficient on the base rate, but it is rather low (.27) and not statistically distinguishable from the coefficient on soft pegs. They also have a significant coefficient on local inflation and an F-test that signals joint significance of the local conditions at the $90 \%$ level). The R-squared for the emerging market sample are lower than for the advanced sample suggesting the policy rules specified may not do as good a job capturing the policy rules. Also, as noted in section IV, the advanced economies have across the board higher $\beta$ coefficients than the emerging market countries, but the pattern that pegs have higher $\beta$ than other regimes is consistent across both sets of countries.

In general, the results in table 7 seem supportive of the notion that low $\beta s$ can be interpreted as providing room for monetary autonomy. Figure 4 summarizes the results by graphing the $\beta s$ against the 
F-stat on the local variables. ${ }^{29}$ There is a noticeable downward trend where higher $\beta$ s correlate with lower F-stats. Despite using only annual data to test for a reaction to the domestic economy and despite enforcing the coefficients be the same across country and time, we frequently find soft pegs and floats showing more reaction to the local economy than pegs while pegs have a higher coefficient on the base country interest rate.

\section{VI: Conclusion}

Concerns with international capital flows have once again raised the topic of whether capital controls offer an attractive policy option. An important aspect of that debate is whether targeted, temporary capital controls offer some degree of monetary autonomy. Likewise, in the wake of difficulties associated with fixed exchange rates, questions are being raised, yet again, about the desirability of limited exchange rate flexibility. The results presented suggest one should consider these middle-ground steps with some caution. We present evidence that soft pegs allow for greater scope over monetary policy than pegs in particular in emerging and developing countries. But there is less evidence that narrowly targeted, temporary capital controls, like those advocated in the theoretical literature (typically for reasons of financial stability) enable monetary authorities to gain autonomy when exchange rates are pegged. Episodic controls are only effective if they are targeted to a wide set of assets, and even here, their effects are uncertain. That is, gates only work if they are much like walls, but, of course, broad capital controls may introduce costly distortions. The main message of our paper is the re-affirmation of the standard result from international macroeconomics; the simplest and most certain means for achieving some measure of monetary autonomy is to allow the exchange rate to float.

\footnotetext{
${ }^{29}$ The different samples have roughly the same number of observations and clusters so the significance levels of the F-stats roughly correspond to the value of the F-stat.
} 


\section{References}

Aizenman, Joshua, (2011) "The Impossible Trinity - from the Policy Trilemma to the Policy Quadrilemma” University of California at Santa Cruz working paper, 2011

Aizenman, Joshua, Menzie D. Chinn, and Hiro Ito (2010). "The Emerging Global Financial Architecture: Tracing and Evaluating the New Patterns of the Trilemma's Configurations", Journal of International Money and Finance, Vol. 29, No. 4, p. 615-641.

Aizenman, Joshua, and Hiro Ito, "Trilemma Policy Convergence Patterns and Output Volatility," working paper, January 2012.

Bianchi, Javier. 2011. "Overborrowing and Systemic Externalities in the Business Cycle." American Economic Review 101, no. 7: 3400-26.

Bluedorn, John and Christopher Bowdler, (2010) "The Empirics of International Monetary Transmission: Exchange Rate Regimes and Interest Rate Pass-through" Journal of Money, Credit and Banking, Volume 42, Issue 4, pages 679-713, June 2010.

Calvo, Guillermo, and Carmen Reinhart, (2002) "Fear of Floating," Quarterly Journal of Economics, vol 117, 379-408.

Chinn, Menzie D. and Hiro Ito (2006). "What Matters for Financial Development? Capital Controls, Institutions, and Interactions," Journal of Development Economics, Volume 81, Issue 1, Pages 163-192 (October).

Clarida, Richard, Jordi Gali, and Mark Gertler, (1998), "Monetarly Policy Rules in Practice: Some International Evidence," European Economic Review 42, 1033-67.

Farhi, Emmanuel and Ivan Werning, (2012), "Dealing with the Trilemma: Optimal Capital Controls with Fixed Exchange Rates," NBER Working Paper no 18199.

Fischer, Stanley, (2001), “Exchange Rate Regimes: Is the Bipolar View Correct?” Journal of Economic Perspectives, vol. 15, no. 2, Spring, pp. $3-24$.

Frankel, Jeffrey A., Sergio L. Schmukler, and Luis Serven, (2004) "Global Transmission of Interest Rates: Monetary Independence and Currency Regimes," Journal of International Money and Finance, 23 (5), 701-34.

Jeanne, Olivier. 2011. "Capital Account Policies and the Real Exchange Rate.” Johns Hopkins University (February). , (2012), "Capital Flow Management." American Economic Review Papers and Proceedings (May): 203-06. 
and Anton Korinek, (2010) "Managing Capital Flows: A Pigouvian Taxation Approach.” American Economic Review Papers and Proceedings (May): 403-07.

Klein, Michael W., (2012), “Capital Controls: Gates versus Walls”, Brookings Papers on Economic Activity, 2013, vol. 2, Fall.

and Jay C. Shambaugh, "Fixed Exchange Rates and Trade," Journal of International Economics, volume 70, issue 2, December 2006, pp. 359 - 383.

, (2008). "The Dynamics of Exchange Rate Regimes: Fixes, Floats, and Flips," Journal of International Economics Volume 75, Issue 1, Pages 70-92 .

, (2010), Exchange Rate Regimes in the Modern Era (MIT Press, Cambridge)

Korinek, Anton, (2010), "Regulating Capital Flows to Emerging Markets: An Externality View." University of Maryland (December).

, (2011), "The New Economics of Prudential Capital Controls: A Research Agenda." IMF Economic Review 59, no. 3: 523-61.

Levy-Yeyati, Eduardo and Federico Sturzenegger, 2003, "To Float or Fix: Evidence on the Impact of Exchange Rate Regimes on Growth," American Economic Review, November, vol. 93, no. 4, pp. 1173 1193.

Miniane, Jacques and John H. Rogers, (2007), "Capital Controls and the International Transmission of U.S. Money Shocks," Journal of Money, Credit and Banking, Vol. 39, No. 5 (August 2007)

Obstfeld, Maurice, Jay C. Shambaugh, and Alan M. Taylor, (2004) "Monetary Sovereignty, Exchange Rates, and Capital Controls: The Trilemma in the Interwar period," IMF Staff Papers, Special Issue, 51, 75-108.

, (2005) "The Trilemma in History: Tradeoffs among Exchange Rates, Monetary Policies, and Capital Mobility," Review of Economics and Statistics, 87 (3), 423-38.

, (2010) Financial Stability, the Trilemma, and International Reserves, American

Economic Association Journal - Macroeconomics vol. 2, no. 2, April 2010, pp. 57-94.

Popper, Helen, Alex Mandilaras, and Graham Bird, 2012, "A New Measure of the Stability of Exchange Rate Arrangements in the Context of the Trilemma"

Reinhart, Carmen M., and Kenneth S. Rogoff. 2004. The Modern History of Exchange Rate Arrangements: A Reinterpretation. Quarterly Journal of Economics, 119:1, 1-48.

Schindler, Martin. 2009. "Measuring Financial Integration: A New Data Set." IMF Staff Papers 56, no 1: 222-38. 
Schmitt-Grohe, Stephanie and Martin Uribe, (2012), "Prudential Policy for Peggers," NBER Working Paper no. 18031.

Shambaugh, Jay, C., (2004) “The Effect of Fixed Exchange Rates on Monetary Policy," Quarterly Journal of Economics, vol. 119 no.1, p. 301-352. 
Figure 1: The Open Economy Policy Trilemma

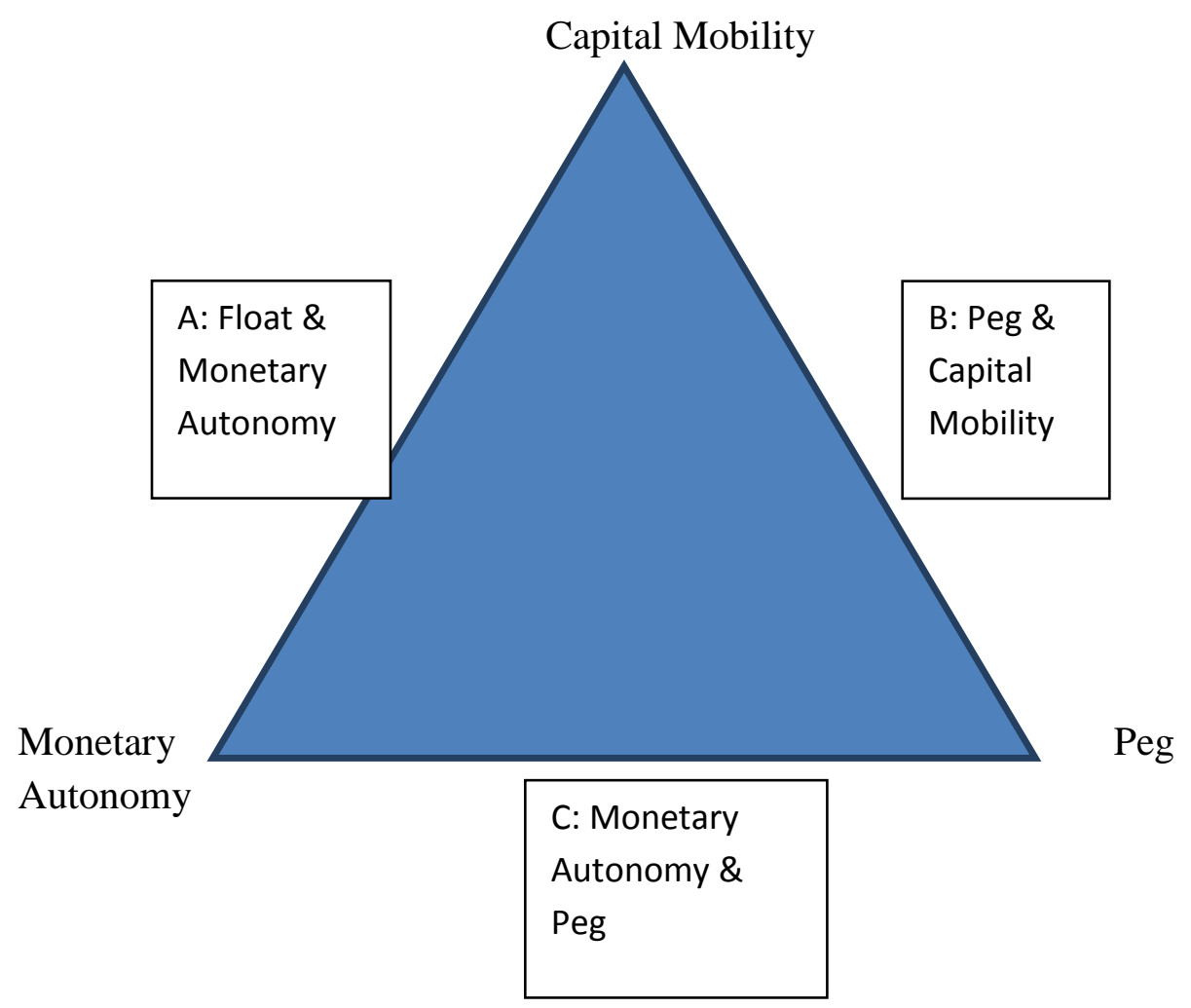


Figure 2: Chinn-Ito Capital Account Indicators Values and Ranges for 3 Dummy Variables

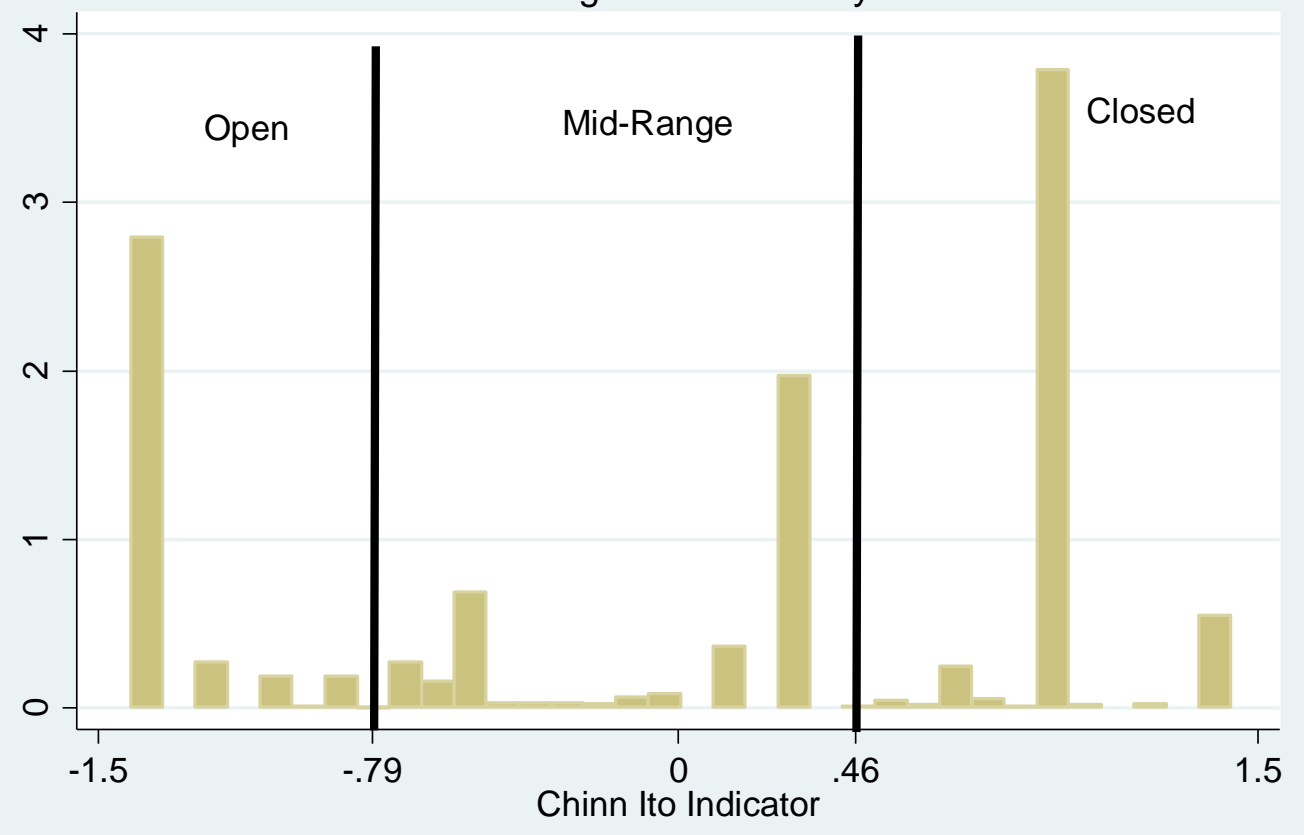


Figure 3: scatters of change in own interest rate and change in base interest rate across samples

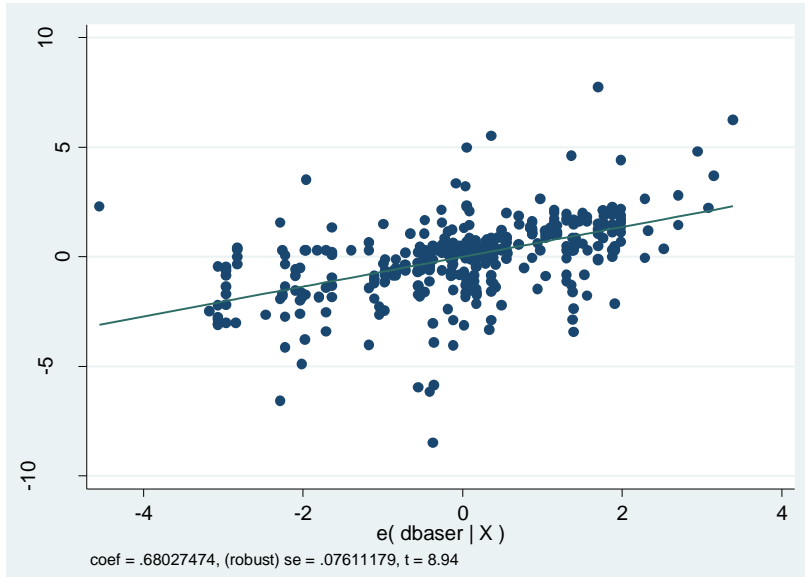

Open pegs

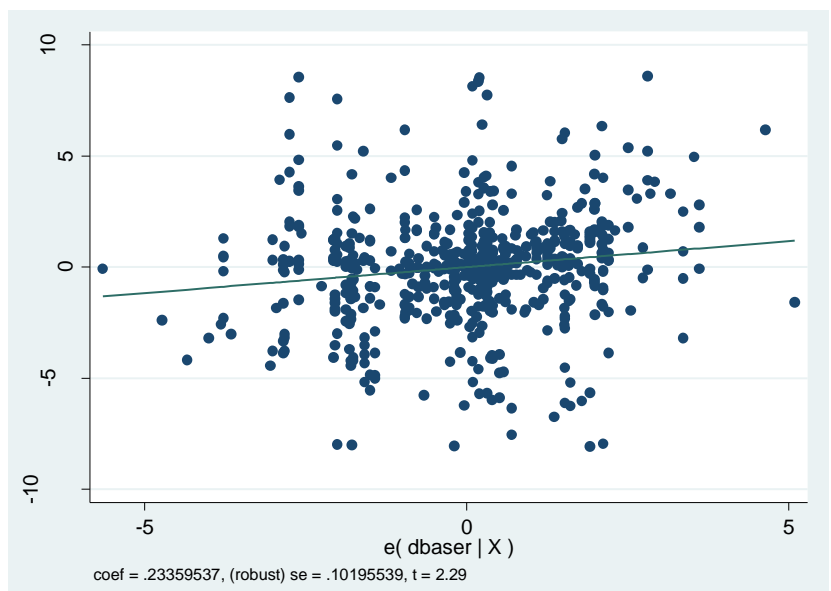

Open non pegs

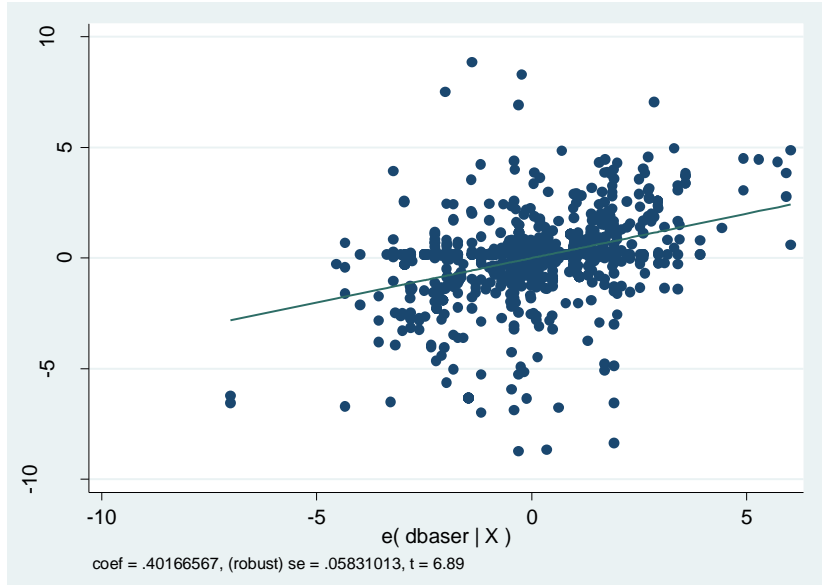

closed pegs

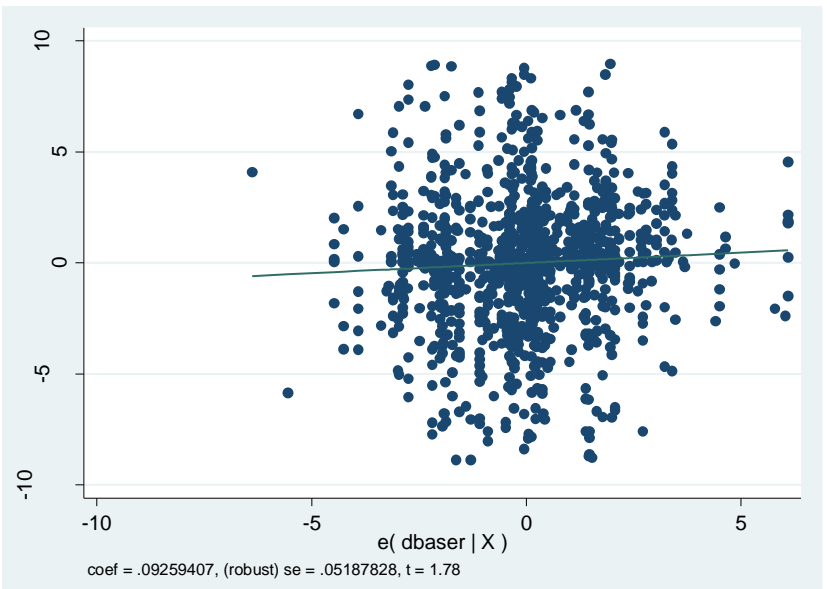

closed nonpegs 
Figure 4: Relationship between correlation of local and base rates and the significance of local conditions in the policy reaction function

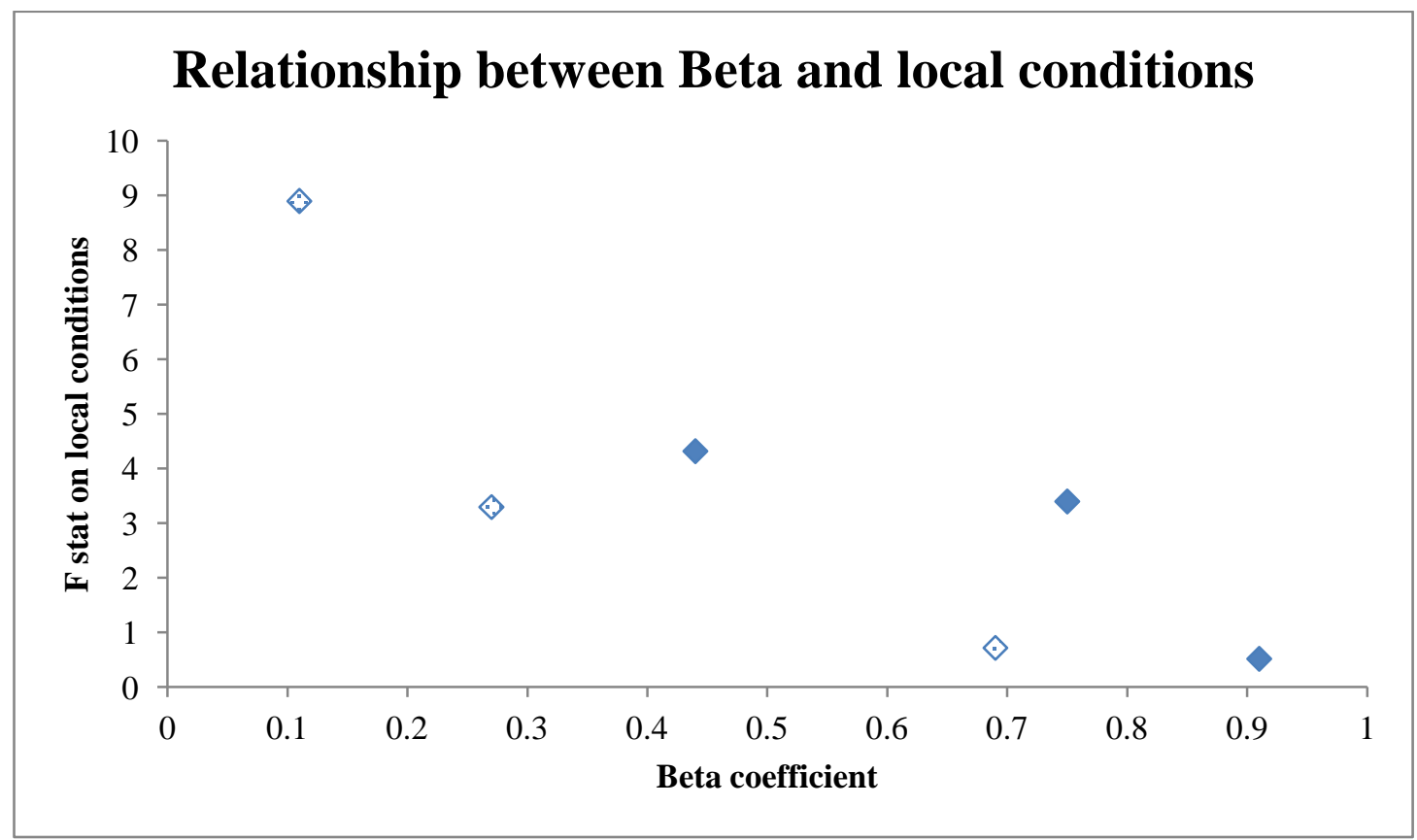

Note: see text for details, full regression results are found in table 7. Solid points represent advanced economy subsamples and dotted points represent emerging samples. 


\begin{tabular}{|c|c|c|c|c|}
\hline \multicolumn{5}{|c|}{ Table 1A: Exchange Rate Categorization } \\
\hline & Peg & Soft Peg & Float & Total \\
\hline Chinn-Ito Data Set & $\mathbf{1 , 4 0 4}$ & $\mathbf{8 0 3}$ & $\mathbf{9 1 9}$ & $\mathbf{3 , 1 2 6}$ \\
\hline 1973- 2011 & $\mathbf{4 5 \%}$ & $\mathbf{2 6 \%}$ & $\mathbf{2 9 \%}$ & \\
\hline Gates Walls Data Set & $\mathbf{4 8 4}$ & $\mathbf{3 9 9}$ & $\mathbf{3 9 3}$ & $\mathbf{1 , 2 7 6}$ \\
\hline $1995-2011$ & $\mathbf{3 8 \%}$ & $\mathbf{3 1 \%}$ & $\mathbf{3 1 \%}$ & \\
\hline
\end{tabular}

\begin{tabular}{|l|l|l|}
\hline \multicolumn{3}{|l|}{ Table 1B: Capital Control Indicators } \\
\hline Chinn-Ito Indicators (country-year) \\
\hline Open & Mid-Range & Closed \\
\hline $\mathbf{1 , 0 1 4}$ & $\mathbf{9 6 1}$ & $\mathbf{1 , 1 5 1}$ \\
\hline $\mathbf{3 2 \%}$ & $\mathbf{3 1 \%}$ & $\mathbf{3 7 \%}$ \\
\hline Gates-Walls Indicator (country) \\
\hline Open & Gates & Walls \\
\hline $\mathbf{3 7 6}$ & $\mathbf{6 1 0}$ & $\mathbf{2 9 0}$ \\
\hline $\mathbf{2 9 \%}$ & $\mathbf{4 8 \%}$ & $\mathbf{2 3 \%}$ \\
\hline
\end{tabular}

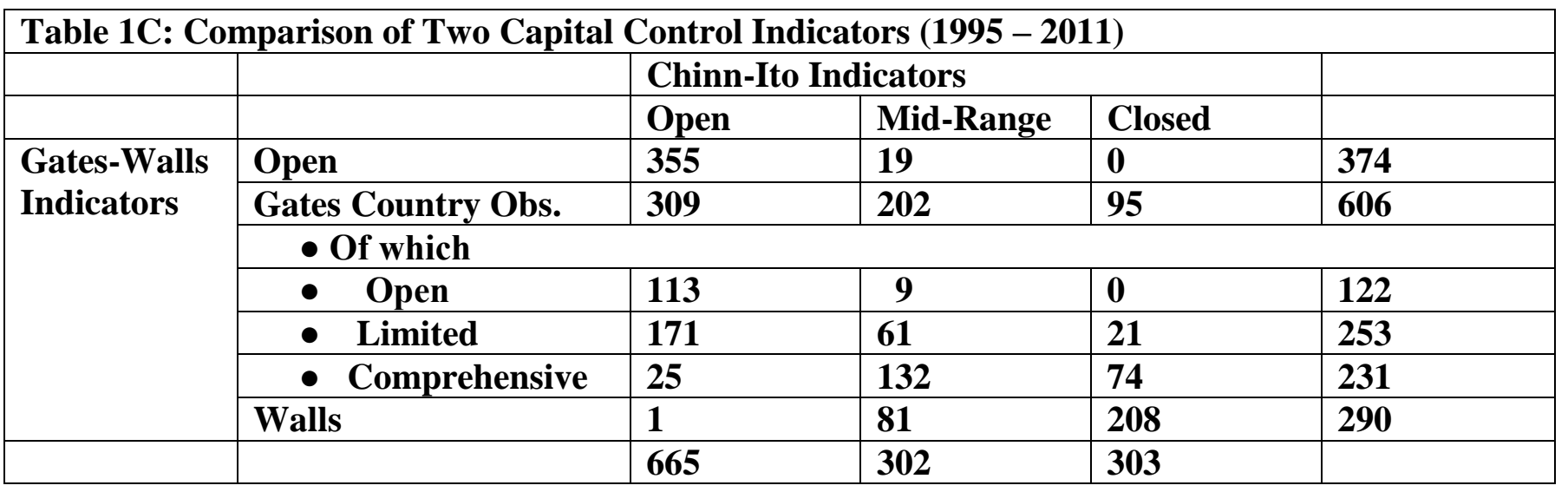

Note: there are 6 observations in the GWO data set that are not in the Chinn-Ito data set, so the totals do not match across table $1 \mathrm{~B}$ and $1 \mathrm{C}$. 


\begin{tabular}{|c|c|c|c|}
\hline & Peg & Non-Peg & Open vs Non-Open \\
\hline Open & $\begin{array}{ll}0.68 * * & 435 \\
(0.08) & {[0.28]}\end{array}$ & $\begin{array}{ll}0.23 * & 579 \\
(0.10) & {[0.02]}\end{array}$ & \multirow[t]{2}{*}{$\begin{array}{l}-0.27 * * \\
(0.07)\end{array}$} \\
\hline Non-Open & $\begin{array}{ll}0.40 * * & 969 \\
(0.06) & {[0.14]}\end{array}$ & $\begin{array}{cc}0.09+ & 1,143 \\
(0.05) & {[0.00]}\end{array}$ & \\
\hline Peg vs. Non-Peg & \multicolumn{2}{|l|}{$\begin{array}{l}0.33^{* *} \\
(0.06)\end{array}$} & \\
\hline KEY & \multicolumn{3}{|l|}{$\begin{array}{ll}\text { Coef. } & \mathbf{N} \\
\text { (s.e.) } & {\left[\mathbf{R}^{2}\right]}\end{array}$} \\
\hline \multicolumn{4}{|c|}{$\begin{array}{l}\text { Chinn-Ito trivariate classification for Peg, Closed. 1973-2011 } \\
2 \times 2 \text { entries based on subsample regressions. } \\
\text { Entries in marginal column and row based on an interaction regression } \\
* * p<0.01, * p<0.05,+p<0.10\end{array}$} \\
\hline
\end{tabular}

\begin{tabular}{|c|c|c|c|c|c|}
\hline & Peg & Soft Peg & Float & vs. Mid-Open & vs. Closed \\
\hline Open & $\begin{array}{ll}0.68 * * & 435 \\
(0.08) & {[0.28]}\end{array}$ & $\begin{array}{ll}\mathbf{0 . 3 1} * & 300 \\
(\mathbf{0 . 1 3}) & {[0.04]} \\
\end{array}$ & $\begin{array}{ll}0.17 & 279 \\
(0.14) & {[0.01]} \\
\end{array}$ & $\begin{array}{l}-0.06 \\
(0.08)\end{array}$ & $\begin{array}{l}-0.29 * * \\
(0.09)\end{array}$ \\
\hline Mid-Open & $\begin{array}{ll}0.54 * * & 439 \\
(0.06) & {[0.22]}\end{array}$ & $\begin{array}{l}\mathbf{0 . 3 8} * 273 \\
(\mathbf{0 . 0 8})[0.05]\end{array}$ & $\begin{array}{ll}0.07 & 249 \\
(0.08) & {[0.00]}\end{array}$ & & \\
\hline Closed & $\begin{array}{ll}0.25 * * & 530 \\
(0.07) & {[0.07]}\end{array}$ & $\begin{array}{ll}0.18+ & 230 \\
(0.10) & {[0.01]}\end{array}$ & $\begin{array}{ll}-0.06 & 391 \\
(0.11) & {[0.00]}\end{array}$ & $\begin{array}{l}0.22^{* * *} \\
(0.06)\end{array}$ & \\
\hline vs. Soft Peg & $\begin{array}{l}0.19 * * \\
(0.07) \\
\end{array}$ & & $\begin{array}{l}0.22 * * \\
(0.08) \\
\end{array}$ & & \\
\hline vs. Float & $\begin{array}{l}0.41 * * \\
(0.07)\end{array}$ & & & KEY & $\begin{array}{ll}\text { Coef. } & \mathbf{N} \\
\text { (s.e.) } & {\left[\mathbf{R}^{2}\right]}\end{array}$ \\
\hline
\end{tabular}

Capital control / exchange rate regime subsamples. 1973-2011

$3 \times 3$ entries based on subsample regressions.

Entries in marginal columns and rows based on an interaction regression

** $\mathbf{p}<0.01, * \mathbf{p}<0.05,+\mathbf{p}<0.10$

OLS 


\begin{tabular}{|c|c|c|c|c|c|c|c|}
\hline \multicolumn{8}{|c|}{ Table 4: Peg Subsamples by Duration of Spell and Years in Spell } \\
\hline & All Pegs & $\begin{array}{l}\text { Long } \\
\text { Pegs }\end{array}$ & $\begin{array}{l}\text { Short } \\
\text { Pegs }\end{array}$ & $\begin{array}{l}\text { Later } \\
\text { Years of } \\
\text { Long Pegs }\end{array}$ & $\begin{array}{l}\text { Early } \\
\text { Years of } \\
\text { Pegs }\end{array}$ & $\begin{array}{l}\text { Long } \\
\text { Nonpegs }\end{array}$ & $\begin{array}{l}\text { Short } \\
\text { Nonpegs }\end{array}$ \\
\hline $\begin{array}{l}\Delta \mathbf{R}_{\mathbf{i}, \mathbf{t}} \\
\text { (s.e.) }\end{array}$ & $\begin{array}{l}0.459 * * \\
(0.049)\end{array}$ & $\begin{array}{l}0.459 * * \\
(0.052)\end{array}$ & $\begin{array}{l}0.476 * * \\
(0.118)\end{array}$ & $\begin{array}{l}0.473 * * \\
(0.054)\end{array}$ & $\begin{array}{l}0.465 * * \\
(0.085)\end{array}$ & $\begin{array}{l}.139 * * \\
(0.052)\end{array}$ & $\begin{array}{l}.133 \\
(0.091)\end{array}$ \\
\hline $\begin{array}{l}\text { Constant } \\
\text { (s.e.) }\end{array}$ & $\begin{array}{l}-0.153 * * \\
(0.040)\end{array}$ & $\begin{array}{l}-0.092 * * \\
(0.030)\end{array}$ & $\begin{array}{l}-0.474 * \\
(0.190)\end{array}$ & $\begin{array}{l}-0.013 \\
(0.026)\end{array}$ & $\begin{array}{l}-0.515 * * \\
(0.127)\end{array}$ & $\begin{array}{l}-0.144 * * \\
(0.054)\end{array}$ & $\begin{array}{l}0.558 * * \\
(0.196)\end{array}$ \\
\hline $\mathbf{R}^{2}$ & 0.168 & 0.216 & 0.081 & 0.252 & 0.099 & 0.001 & 0.013 \\
\hline $\mathbf{N}$ & 1,404 & $\mathbf{1 , 1 8 1}$ & 223 & $\mathbf{1 , 0 0 0}$ & 381 & 1604 & 118 \\
\hline \multicolumn{8}{|c|}{$\begin{array}{l}* * p<0.01, * p<0.05,+p<0.10 \\
\text { Long Pegs }- \text { peg spells with duration greater than or equal to } 5 \text { years } \\
\text { Short Pegs - peg spells with duration less than or equal to } 4 \text { years } \\
\text { Later Years of Long Pegs - Years } 5 \text { and following for Long Peg Spells } \\
\text { Early Years of Pegs - First } 4 \text { years of Peg Spells }\end{array}$} \\
\hline
\end{tabular}

\begin{tabular}{|c|c|c|c|c|c|c|}
\hline \multicolumn{7}{|c|}{ Table 5: Gates, Walls, Open: Subsample Regressions } \\
\hline & Open & \begin{tabular}{|l|} 
Open \\
Gates
\end{tabular} & $\begin{array}{l}\text { Any Closed } \\
\text { Gates }\end{array}$ & $\begin{array}{l}\text { Limited } \\
\text { Gates }\end{array}$ & $\begin{array}{l}\text { Comprehensive } \\
\text { Gates }\end{array}$ & Walls \\
\hline $\begin{array}{l}\Delta \mathbf{R}_{\mathrm{i}, \mathrm{t}}(\mathbf{p e g}) \\
\text { (s.e.) }\end{array}$ & $\begin{array}{l}0.710 * * \\
(0.083) \\
\end{array}$ & $\begin{array}{l}0.608 * * \\
(0.204) \\
\end{array}$ & $\begin{array}{l}0.704 * * \\
(0.145) \\
\end{array}$ & $\begin{array}{l}0.857 * * \\
(0.105)\end{array}$ & $\begin{array}{l}0.489^{+} \\
(0.253)\end{array}$ & $\begin{array}{l}0.286 \\
(0.194) \\
\end{array}$ \\
\hline $\begin{array}{l}\Delta \mathbf{R}_{\mathrm{i}, \mathrm{t}} \text { (non- } \\
\text { peg) } \\
(\mathrm{s.e})\end{array}$ & $\begin{array}{l}0.107 \\
(0.190)\end{array}$ & $\begin{array}{l}0.133 \\
(0.272)\end{array}$ & $\begin{array}{l}0.026 \\
(0.119)\end{array}$ & $\begin{array}{l}0.040 \\
(0.146)\end{array}$ & $\begin{array}{l}-\mathbf{- 0 . 0 1 9} \\
(0.160)\end{array}$ & $\begin{array}{l}0.145 \\
(0.193)\end{array}$ \\
\hline $\begin{array}{l}\text { Dif. peg and } \\
\text { non-peg }\end{array}$ & $\begin{array}{l}0.603 * * \\
(0.208)\end{array}$ & $\begin{array}{l}0.475 \\
(0.340)\end{array}$ & $\begin{array}{l}0.678 * * \\
(0.185)\end{array}$ & $\begin{array}{l}0.817 * * \\
(0.189)\end{array}$ & $\begin{array}{l}0.508 \\
(0.300) \\
\end{array}$ & $\begin{array}{l}0.141 \\
(0.232) \\
\end{array}$ \\
\hline $\mathbf{R}^{2}$ & 0.070 & $\begin{array}{l}0.046 \\
\end{array}$ & 0.030 & 0.059 & 0.013 & 0.016 \\
\hline $\mathbf{N}$ & 376 & 123 & 487 & 255 & 232 & 290 \\
\hline \multicolumn{7}{|c|}{$\begin{array}{l}* * p<0.01, * \mathrm{p}<0.05,{ }^{+} \mathrm{p}<0.10 \\
\text { Open Gates - Gate countries with no controls in that year. } \\
\text { Any Closed Gates - Gate countries with any controls in that year. } \\
\text { Limited Gates - Gate countries with half or fewer categories controlled in that year. } \\
\text { Comprehensive Gates - Gate countries with more than half of categories controlled in that year }\end{array}$} \\
\hline
\end{tabular}




\begin{tabular}{|c|c|c|c|c|c|}
\hline & Open & Open Gates & $\begin{array}{l}\text { Limited } \\
\text { Gates }\end{array}$ & $\begin{array}{l}\text { Comprehensive } \\
\text { Gates }\end{array}$ & Walls \\
\hline Open & - & $\begin{array}{l}-0.112 \\
(0.209)\end{array}$ & \begin{tabular}{|l|}
$\mathbf{0 . 1 6 5}$ \\
$(\mathbf{0 . 1 3 9})$
\end{tabular} & $\begin{array}{l}-\mathbf{- 0 . 1 8 5} \\
(0.245)\end{array}$ & $\begin{array}{l}-\mathbf{- 0 . 4 0 0 *} \\
(0.199)\end{array}$ \\
\hline Open Gates & $\begin{array}{l}0.030 \\
(0.321)\end{array}$ & - & $\begin{array}{l}0.277 \\
(0.234)\end{array}$ & $\begin{array}{l}-0.073 \\
(0.310)\end{array}$ & $\begin{array}{l}-0.288 \\
(0.265)\end{array}$ \\
\hline Limited Gates & $\begin{array}{l}-0.103 \\
(0.245)\end{array}$ & $\begin{array}{l}-0.132 \\
(0.309)\end{array}$ & - & \begin{tabular}{|l|}
-0.350 \\
$(0.254)$
\end{tabular} & $\begin{array}{l}-0.565 * \\
(0.214)\end{array}$ \\
\hline $\begin{array}{l}\text { Comprehensive } \\
\text { Gates }\end{array}$ & $\begin{array}{l}-\mathbf{0 . 0 8 8} \\
(0.239)\end{array}$ & $\begin{array}{l}-0.118 \\
(0.306)\end{array}$ & $\begin{array}{l}0.014 \\
(0.223)\end{array}$ & - & $\begin{array}{l}-0.215 \\
(0.294)\end{array}$ \\
\hline Walls & $\begin{array}{l}0.017 \\
(0.268)\end{array}$ & $\begin{array}{l}-0.013 \\
(0.330)\end{array}$ & $\begin{array}{l}0.119 \\
(0.258)\end{array}$ & $\begin{array}{l}0.105 \\
(0.251)\end{array}$ & - \\
\hline \multicolumn{6}{|c|}{$\begin{array}{l}* * p<0.01, * p<0.05,+p<0.10 \\
\text { Results in upper diagonal are associated with peg country sample while results in lower } \\
\text { diagonal are associated with non-peg country sample. }\end{array}$} \\
\hline
\end{tabular}




\begin{tabular}{|c|c|c|c|}
\hline \multicolumn{4}{|c|}{ Table 7: Autonomy for What? Advanced Country Subsamples } \\
\hline & Peg & Soft Peg & Float \\
\hline$\Delta \mathbf{R}_{\mathbf{i}, \mathbf{t}}$ & $\begin{array}{l}\text { O.91*** } \\
(0.14)\end{array}$ & \begin{tabular}{|l|}
$0.75 * *$ \\
$(0.14)$
\end{tabular} & \begin{tabular}{|l}
$0.44 * *$ \\
$(0.16)$
\end{tabular} \\
\hline$\Delta \pi_{t-1}$ & \begin{tabular}{|l|}
0.06 \\
$(\mathbf{0 . 0 6})$
\end{tabular} & \begin{tabular}{|l|}
$\mathbf{0 . 3 3} *$ \\
$(\mathbf{0 . 1 3})$ \\
\end{tabular} & \begin{tabular}{|l|}
0.19 \\
$(0.18)$ \\
\end{tabular} \\
\hline$\Delta \ln Y_{t-1}$ & \begin{tabular}{|l|}
-1.51 \\
$(4.15)$
\end{tabular} & \begin{tabular}{|l|}
6.03 \\
$(6.58)$
\end{tabular} & $\begin{array}{l}14.37 * * * \\
(5.00)\end{array}$ \\
\hline F-stat & 0.6 & 3.4+ & $4.3^{*}$ \\
\hline $\mathbf{N}$ & 171 & 128 & 122 \\
\hline $\mathbf{R}^{2}$ & 0.54 & 0.45 & 0.29 \\
\hline \multicolumn{4}{|c|}{ Emerging Market Subsamples } \\
\hline & Peg & \begin{tabular}{|l|} 
Soft Peg \\
\end{tabular} & Float \\
\hline$\Delta \mathbf{R}_{\mathbf{i}, \mathbf{t}}$ & $\begin{array}{l}\mathbf{0 . 6 9 * *} \\
(\mathbf{0 . 2 0})\end{array}$ & \begin{tabular}{|l|}
0.11 \\
$(0.16)$
\end{tabular} & \begin{tabular}{|l|}
$0.27 *$ \\
$(\mathbf{0 . 1 0})$
\end{tabular} \\
\hline$\Delta \pi_{t-1}$ & \begin{tabular}{|l|}
0.00 \\
$(\mathbf{0 . 0 6})$
\end{tabular} & \begin{tabular}{|l}
$0.30 * *$ \\
$(0.08)$
\end{tabular} & \begin{tabular}{|l|} 
0.32* \\
$(\mathbf{0 . 1 3})$
\end{tabular} \\
\hline$\Delta \ln Y_{t-1}$ & \begin{tabular}{|l|}
$\mathbf{3 . 8 6}$ \\
$\mathbf{( 3 . 3 2 )}$
\end{tabular} & \begin{tabular}{|l|}
5.20 \\
$(12.45)$
\end{tabular} & \begin{tabular}{|l|}
-5.29 \\
$(5.63)$
\end{tabular} \\
\hline F-stat & 0.5 & 8.9 ** & 3.3+ \\
\hline $\mathbf{N}$ & 103 & 128 & 111 \\
\hline $\mathbf{R}^{2}$ & 0.22 & 0.19 & $\mathbf{0 . 1 3}$ \\
\hline
\end{tabular}

Note: subsamples for 1990-2011 for open and mid-open capital accounts. 


\section{APPENDIX TABLES}

\begin{tabular}{|c|c|c|c|}
\hline $\begin{array}{l}\text { Appendix Table 2a: } \\
\text { 2x2 Classification of Ex }\end{array}$ & change Rate aı & al Control Re & r Fixed Effects \\
\hline & Peg & Non-Peg & Open vs Non-Open \\
\hline Open & $\begin{array}{ll}0.64 * * & 435 \\
(0.10) & {[0.45]}\end{array}$ & $\begin{array}{ll}0.02 & 579 \\
(0.10) & {[0.16]}\end{array}$ & $\begin{array}{l}-0.27 * * \\
(0.07)\end{array}$ \\
\hline Non-Open & $\begin{array}{ll}0.36 * * & 969 \\
(0.07) & {[0.26]}\end{array}$ & $\begin{array}{cr}-\mathbf{- 0 . 0 6} & 1,143 \\
(0.08) & {[0.09]}\end{array}$ & \\
\hline Peg vs. Non-Peg & $\begin{array}{l}0.29 * * \\
(0.06)\end{array}$ & & \\
\hline KEY & $\begin{array}{ll}\text { Coef. } & \mathbf{N} \\
\text { (s.e.) } & {\left[\mathbf{R}^{2}\right]}\end{array}$ & & \\
\hline $\begin{array}{l}\text { Chinn-Ito trivariate cla } \\
\text { Marginal variables ref } \\
* * p<0.01, * p<0.05,+\end{array}$ & $\begin{array}{l}\text { sssification for } \\
\text { er to an intera } \\
0<0.10\end{array}$ & $\begin{array}{l}\text { d. 1973-2011 } \\
\text { ssion }\end{array}$ & Fixed Effects \\
\hline
\end{tabular}

\begin{tabular}{|c|c|c|c|c|c|}
\hline \multicolumn{6}{|c|}{$\begin{array}{l}\text { Appendix Table 3a: } 3 \text { x } 3 \text { Classification of Exchange Rate and Capital Control Regimes } \\
\text { Year Fixed Effects }\end{array}$} \\
\hline \multirow[b]{2}{*}{ Open } & \multirow{2}{*}{$\begin{array}{l}\text { Peg } \\
0.64 * 4 * 435 \\
(0.11) \\
{[0.40]}\end{array}$} & \multirow{2}{*}{ 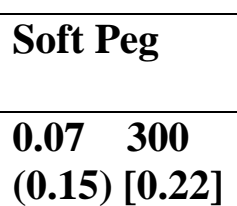 } & \multirow{2}{*}{\begin{tabular}{|ll} 
Float \\
\\
$\mathbf{- 0 . 1 5}$ & $\mathbf{2 7 9}$ \\
$(0.17)$ & {$[0.24]$} \\
\end{tabular}} & \multirow{2}{*}{$\begin{array}{l}\begin{array}{l}\text { vs. Mid- } \\
\text { Open }\end{array} \\
-0.11 \\
(0.08)\end{array}$} & \multirow{2}{*}{$\begin{array}{l}\text { vs. Closed } \\
-0.31 * * \\
(0.09)\end{array}$} \\
\hline & & & & & \\
\hline Mid-Open & $\begin{array}{ll}0.41 * * & 439 \\
(0.08) & {[0.42]}\end{array}$ & $\begin{array}{ll}0.18 & 273 \\
(0.14) & {[0.34]}\end{array}$ & $\left.\begin{array}{ll}-0.31 & 249 \\
(0.23) & {[0.22}\end{array}\right]$ & & \\
\hline Closed & $\begin{array}{ll}0.38 * * & 530 \\
(0.07) & {[0.19]}\end{array}$ & $\begin{array}{l}-0.14230 \\
(0.16)[0.16]\end{array}$ & $\begin{array}{ll}-0.08 & 391 \\
(0.13) & {[0.14]}\end{array}$ & $\begin{array}{l}0.20 * * \\
(0.07)\end{array}$ & \\
\hline vS. Soft Peg & $\begin{array}{l}0.16^{*} \\
(0.07)\end{array}$ & & $\begin{array}{l}0.21 * \\
(0.08)\end{array}$ & & \\
\hline vs. Float & $\begin{array}{l}0.37 * * \\
(0.07)\end{array}$ & & & KEY & $\begin{array}{ll}\text { Coef. } & \mathbf{N} \\
\text { (s.e.) } & {\left[\mathbf{R}^{2}\right]}\end{array}$ \\
\hline $\begin{array}{l}\text { Capital cont } \\
\text { Marginal va } \\
* * \mathbf{p}<0.01, *\end{array}$ & $\begin{array}{l}\text { / exchange rat } \\
\text { oles refer to an } \\
0.05,+p<0.10\end{array}$ & gime sub & $\begin{array}{l}\text { es. 1973-20 } \\
\text { sion }\end{array}$ & & Fixed Effects \\
\hline
\end{tabular}


Table 4a: Interaction regression with additional controls

\begin{tabular}{|c|c|c|}
\hline & $\begin{array}{c}1 \\
\text { full }\end{array}$ & $\begin{array}{c}2 \\
\text { full }\end{array}$ \\
\hline$\Delta$ base $\mathrm{R}$ & $\begin{array}{c}-0.149+ \\
(0.08)\end{array}$ & $\begin{array}{c}-0.214 * \\
(0.085\end{array}$ \\
\hline peg $* \Delta$ base $\mathrm{R}$ & $\begin{array}{r}0.445 * * \\
(0.073)\end{array}$ & $\begin{array}{r}0.512 * * \\
(0.074)\end{array}$ \\
\hline softpeg $* \Delta$ base $\mathrm{R}$ & $\begin{array}{c}0.265^{* *} \\
(0.084)\end{array}$ & $\begin{array}{c}0.269 * * \\
(0.082)\end{array}$ \\
\hline open $* \Delta$ base $\mathrm{R}$ & $\begin{array}{c}0.310 * * \\
(0.091)\end{array}$ & $\begin{array}{l}0.205^{*} \\
(0.092)\end{array}$ \\
\hline Mid open $* \Delta$ base $\mathrm{R}$ & $\begin{array}{c}0.237 * * \\
(0.063)\end{array}$ & $\begin{array}{c}0.149 * \\
(0.07)\end{array}$ \\
\hline $\operatorname{Adv} * \Delta$ base $\mathrm{R}$ & & $\begin{array}{c}0.335 * * \\
(0.073)\end{array}$ \\
\hline High reserves $* \Delta$ base $\mathrm{R}$ & & $\begin{array}{c}0.033 \\
(0.071)\end{array}$ \\
\hline Constant & $\begin{array}{c}-0.132 * * \\
(0.03)\end{array}$ & $\begin{array}{c}-0.140 * * \\
(0.03)\end{array}$ \\
\hline Observations & 3,126 & 3,126 \\
\hline $\begin{array}{l}\text { R-squared } \\
* * \mathrm{p}<0.01, * \mathrm{p}<0.05,+\mathrm{p}<0.1\end{array}$ & 0.06 & 0.069 \\
\hline
\end{tabular}

Note: regression in the form of equation (5) with additional controls. 1973-2011 sample. Standard errors clustered by country 